\title{
Sectorrapportage Hoger Technisch Onderwijs
}

Citation for published version (APA):

Allen, J. P., van Thor, J. A. F., \& Verhagen, A. M. C. (2013). Sectorrapportage Hoger Technisch

Onderwijs. ROA. ROA Reports No. 004 https://doi.org/10.26481/umarep.2013004

Document status and date:

Published: 01/01/2013

DOI:

10.26481/umarep.2013004

Document Version:

Publisher's PDF, also known as Version of record

\section{Please check the document version of this publication:}

- A submitted manuscript is the version of the article upon submission and before peer-review. There can be important differences between the submitted version and the official published version of record.

People interested in the research are advised to contact the author for the final version of the publication, or visit the DOI to the publisher's website.

- The final author version and the galley proof are versions of the publication after peer review.

- The final published version features the final layout of the paper including the volume, issue and page numbers.

Link to publication

\footnotetext{
General rights rights.

- You may freely distribute the URL identifying the publication in the public portal. please follow below link for the End User Agreement:

www.umlib.nl/taverne-license

Take down policy

If you believe that this document breaches copyright please contact us at:

repository@maastrichtuniversity.nl

providing details and we will investigate your claim.
}

Copyright and moral rights for the publications made accessible in the public portal are retained by the authors and/or other copyright owners and it is a condition of accessing publications that users recognise and abide by the legal requirements associated with these

- Users may download and print one copy of any publication from the public portal for the purpose of private study or research.

- You may not further distribute the material or use it for any profit-making activity or commercial gain

If the publication is distributed under the terms of Article $25 \mathrm{fa}$ of the Dutch Copyright Act, indicated by the "Taverne" license above, 


\section{Sectorrapportage Hoger Technisch Onderwijs}

Jim Allen

Jesper van Thor

Annelore Verhagen

ROA-R-2013/4 


\section{Colofon}

(C) Researchcentrum voor Onderwijs en Arbeidsmarkt (ROA). Niets uit deze uitgave mag op enige manier worden verveelvoudigd zonder voorafgaande schriftelijke toestemming van de directeur van het ROA.

\section{Researchcentrum voor Onderwijs en Arbeidsmarkt}

School of Business and Economics

Maastricht University

\section{Vormgeving}

ROA secretariaat, Maastricht

\section{Verkoop}

Researchcentrum voor Onderwijs en Arbeidsmarkt email: secretary-roa-sbe@maastrichtuniversity.nl website: www.roa.nl

ISBN: 978-90-532I-509-8

februari 2013 


\section{Inhoud}

1 Inleiding 1

2 De arbeidsmarkt voor afgestudeerden van het HTO 7

3 Arbeidsmarktperspectieven $\quad 21$

4 Vereiste competenties voor afgestudeerden van het HTO 25

$\begin{array}{lll}4.1 & \text { Trends en ontwikkelingen } & 25\end{array}$

$\begin{array}{ll}4.2 \text { Vereist niveau competenties } & 26\end{array}$

$\begin{array}{ll}4.3 \text { Competentietekorten } & 30\end{array}$

5 Conclusie 35

$\begin{array}{ll}\text { Literatuur } & 37\end{array}$

Bijlage: Kernindicatoren voor HTO Bachelor-opleidingen 39 



\section{Inleiding}

De HBO-Monitor vierde in 2010 haar 20-jarige bestaan. In de eerste twintig jaar van de $\mathrm{HBO}-$ Monitor is op verschillende manieren gerapporteerd over de aansluiting tussen het $\mathrm{HBO}$ en de arbeidsmarkt, over de vraag wat de $\mathrm{HBO}$-studenten tijdens hun studie hebben geleerd en over de vraag hoe zij de gevolgde opleiding beoordelen. Hierbij is vooral gericht gerapporteerd op landelijk niveau en op het niveau van de onderwijsinstelling. De tussenliggende laag, de afzonderlijke sectoren, (met uitzondering van de sector kunst), zijn daarbij (met uitzondering van het eerste jaar van de HBO-Monitor) zelden als insteek gekozen. Voor de resterende zes sectoren: Economie, Gezondheidszorg, Landbouw, Pedagogisch, Sociaal-agogisch en Techniek wordt in het kader van het 20-jarige bestaan dan ook een rapport geschreven met de betreffende sector als centraal ankerpunt. Vanuit dit perspectief is de voorliggende rapportage specifiek gericht op de HBO-sector Hoger Technisch Onderwijs (HTO). Hierbij staan de implicaties van recente alsook toekomstige arbeidsmarktontwikkelingen in de sector op de gevraagde competenties van afgestudeerden centraal. Zo wordt achterhaald op welke competenties het onderwijsveld zich de komende jaren zou moeten richten om afgestudeerden optimaal voor te kunnen bereiden op hun beroepsloopbaan in de technisch sector.

De context van deze rapportage wordt gevormd door de strategische agenda $\mathrm{HO}$ en het hoofdlijnenakkoord tussen de HBO-raad en het Ministerie van Onderwijs, Cultuur en Wetenschap (Ministerie van OC\&W, 20II). Hierin worden afspraken gemaakt over het met een zekere regelmaat uitvoeren van sectorale verkenningen. De huidige rapportage in het kader van 20 jaar HBO-Monitor levert relevant materiaal voor die sectorale verkenningen.

\section{Leeswijzer}

Als uitgangspunt voor voorliggende sectorrapportage wordt in hoofdstuk I allereerst kort een algemeen beeld van de sector Techniek geschetst. Vervolgens wordt in hoofdstuk 2 aan de hand van een breed scala aan indicatoren de arbeidsmarktsituatie voor recent afgestudeerden van het Hoger Technisch Onderwijs beschreven. Hierna wordt in hoofdstuk 3 stilgestaan bij de verwachte arbeidsmarktperspectieven voor afgestudeerde technici in de komende jaren. Tot slot wordt in hoofdstuk 4 ingegaan op de competenties die recent afgestudeerden dienen te bezitten en worden in hoofdstuk 5 
de belangrijkste conclusies op een rij gezet. In de bijlage worden de resultaten voor enkele kernindicatoren uitgesplitst naar HTO Bachelor-opleidingen.

\section{HTO cijfermatig in beeld}

Hoewel er in de toekomst grote tekorten aan hoogopgeleide technici worden verwacht, kan er de afgelopen jaren toch een stijgende lijn waargenomen worden in het aantal ingeschreven studenten in deze sector in het hoger beroepsonderwijs (HBO). In $20 \mathrm{IO}$ stonden er in totaal ruim 66.000 studenten ingeschreven bij een technische opleiding op HBO-niveau. De nieuwe instroom in de sector techniek bestond dat jaar uit ruim I7.000 studenten. De afgelopen jaren is van alle technische opleidingen in het HBO bouwkunde de grootste opleiding. Jaarlijks kiezen er gemiddeld zo'n 6.400 studenten voor deze opleiding. HBO informatica is de laatste jaren de op één na grootste technische opleiding. De opleiding communication and multimedia design staat in 2010 op de derde plaats van de grootste technische opleidingen, maar tot 2009 was dit werktuigbouwkunde. Andere grote technische opleidingen zijn technische bedrijfskunde, biologie en medisch laboratoriumonderzoek, civiele techniek, technische informatica en chemie.

\section{Tabel 1.1}

De 10 grootste opleidingen binnen het hoger technisch beroepsonderwijs in 2010

\begin{tabular}{|l|l|r|}
\hline & Opleiding: & Inschrijvingen \\
\hline 1 & bouwkunde & 6.360 \\
\hline 2 & informatica & 6.042 \\
\hline 3 & communication and multimedia design & 5.859 \\
\hline 4 & werktuigbouwkunde & 5.636 \\
\hline 5 & technische bedrifskunde & 4.945 \\
\hline 6 & elektrotechniek & 3.938 \\
\hline 7 & biologie en medisch laboratoriumonderzoek & 3.425 \\
\hline 8 & civiele techniek & 2.488 \\
\hline 9 & technische informatica & 2.033 \\
\hline 10 & chemie & 1.995 \\
\hline & HTO totaal & 65.771 \\
\hline
\end{tabular}

Bron: HBO-Raad (2012) / bewerking ROA

Maar hoe ziet 'de' student $\mathrm{HBO}$ techniek er nu eigenlijk uit? Om hier kort een beeld van te schetsen worden in tabel I.2 een aantal achtergrondkenmerken van recent afgestudeerde HBO'ers met een technische opleidingsachtergrond weergegeven. Om deze achtergrondkenmerken te kunnen duiden worden deze bovendien vergeleken met het $\mathrm{HBO}$-gemiddelde. Uit de tabel blijkt zoals verwacht dat vrouwen beduidend minder dan mannen voor een technische opleiding kozen in de periode. Het aandeel vrouwen in deze sector ( $12,2 \%)$ is dan ook veel lager dan het HBO-gemiddelde. De gemiddelde leeftijd van recent afgestudeerden van $\mathrm{HBO}$ techniek is vrijwel identiek aan die van de totale groep HBO-afgestudeerden. Daarnaast was het aandeel allochtonen 
binnen HBO-techniek iets lager dan gemiddeld. Dit geldt zowel voor westerse als niet-westerse allochtonen. Recent afgestudeerde HBO'ers met een diploma techniek blijken in vergelijking met andere HBO'ers vaker dan gemiddeld een vooropleiding op MBO-niveau gevolgd te hebben en juist minder vaak via $\mathrm{HAVO}$ naar het $\mathrm{HBO}$ door te stromen. Nadat deze technici hun HBO-diploma behaald hebben kiezen zij bovendien relatief minder vaak voor een vervolgopleiding (I6,6\%).

Tot slot van dit hoofdstuk wordt bekeken in welke branches en beroepsgroepen afgestudeerden van het HTO voornamelijk werkzaam zijn kort nadat zij de arbeidsmarkt betreden hebben.

\section{Tabel 1.2}

Achtergrondkenmerken van recent afgestudeerden van het HTO, 2006-2010

\begin{tabular}{|l|r|r|}
\hline Vrouw (\%) & HTO & HBO total \\
\hline Leeftijd (gem.) & 12,2 & 55,9 \\
\hline Allochtoon (\%) & 25,3 & 25,2 \\
\hline westerse & & \\
\hline niet-westerse & 6,0 & 7,2 \\
\hline Hoogst voltooide vooropleiding (\%) & 5,7 & 6,2 \\
\hline HAVO & & \\
\hline VWO & 42,7 & 48,8 \\
\hline MBO & 15,3 & 16,7 \\
\hline HBO & 36,9 & 26,8 \\
\hline andere vooropleiding & 3,4 & 5,3 \\
\hline Vervolgopleiding gevolgd (\%) & 1,7 & 2,3 \\
\hline Bin: & 16,6 & 22,1 \\
\hline
\end{tabular}

Bron: HBO-Monitor 2006-2010

Tabel I.3 laat zien in welke branches recent afgestudeerden van het $\mathrm{HBO}$ met een technische opleidingsachtergrond de afgelopen jaren voornamelijk werkzaam zijn. Twee branches steken er in deze periode duidelijk boven uit. Van de totale groep werkende afgestudeerden van $\mathrm{HBO}$ techniek verrichtte de grootste groep (I6,5\%) dienstverlenende activiteiten op het gebied van informatietechnologie. Daarnaast werkte een substantieel deel van de technische afgestudeerden van het $\mathrm{HBO}$ circa I,5 jaar na afstuderen als architect, ingenieur en technisch ontwerper/adviseur (II,4\%) of voert hiervoor keuringen en controles uit $(3,5 \%)$. De overige afgestudeerden uit deze sector zijn behoorlijk verspreid over een breed scala aan branches. Hoewel het om kleine aandelen gaat, komt eveneens een behoorlijk deel van de afgestudeerden $\mathrm{HBO}$ techniek bijvoorbeeld terecht in advisering op het gebied van management en bedrijfsvoering, openbaar bestuur, vervaardiging van overige machiens, apparaten en werktuigen voor specifieke doeleinden, gegevensverwerking webhosting en aanverwante activiteiten en bouwinstalatie. 
Tabel 1.3

Aandeel werkende recent afgestudeerden van het HTO per branche, 2006-2010

\begin{tabular}{|l|l|r|r|}
\hline 1 & & $\%$ HTO & $\%$ HBO totaal \\
\hline 2 & Dienstverlenende activiteiten op het gebied van informatietechnologie & 16,5 & 4,8 \\
\hline 3 & Architecten, ingenieurs en technisch ontwerp en advies & 11,4 & 2,7 \\
\hline 4 & Algemene burgerlijke en utiliteitsbouw & 4,3 & 0,9 \\
\hline 5 & Ziekenhuizen & 3,7 & 5,8 \\
\hline 6 & Architecten, ingenieurs en technisch ontwerp en advies; keuring en controle & 3,5 & 0,8 \\
\hline 7 & Advisering op het gebied van management en bedrijfsvoering & 2,5 & 2,0 \\
\hline 8 & Openbaar bestuur & 2,3 & 2,7 \\
\hline 9 & Vervaardiging van overige machines, apparaten en werktuigen voor specifieke & 2,2 & 0,5 \\
\hline 10 & doeleinden & 2,0 & 0,7 \\
\hline
\end{tabular}

Bron: HBO-Monitor 2006-2010

In tabel I. 4 wordt eveneens weergegeven in welke branches het gros van de recent afgestudeerden van $\mathrm{HBO}$ techniek de afgelopen jaren werkte. Ditmaal gaat het echter om de branches waar afgestudeerden uit de sector techniek de dominante groep zijn onder werkende HBO'ers. ${ }^{I}$ Van de totale groep recent afgestudeerde en werkende HBO'ers heeft $17,7 \%$ een technische opleidingsachtergrond. Daarmee is dit afgezien van de groep recent afgestudeerden van het Hoger Economisch Onderwijs (35,9\%) de grootste groep onder werkende HBO'ers in de periode 2006-20IO.

\section{Tabel 1.4}

Branches waar recent afgestudeerden van het HTO de dominante groep zijn onder HBO-afgestudeerden, 2006-2010

\begin{tabular}{|l|l|r|}
\hline 1 & Algemene burgerlijke en utiliteitsbouw en projectontwikkeling & $\%$ HTO \\
\hline 2 & Algemene burgerlijke en utiliteitsbouw & 85,6 \\
\hline 3 & Vervaardiging van meet-, regel-, navigatie- en controleapparatuur en van uurwerken & 84,7 \\
\hline 4 & Scheepsbouw & 80,1 \\
\hline 5 & Zee- en kustvaart (vracht-, tank- en sleepvaart) & 80,1 \\
\hline 6 & Architecten, ingenieurs en technisch ontwerp en advies; keuring en controle & 79,2 \\
\hline 7 & Vervaardiging van overige machines, apparaten en werktuigen voor specifieke doeleinden & 78,4 \\
\hline 8 & Architecten, ingenieurs en technisch ontwerp en advies & 76,6 \\
\hline 9 & Bouw van wegen, spoorwegen en kunstwerken & 75,5 \\
\hline 10 & Vervaardiging van elektronische componenten en printplaten & 73,4 \\
\hline
\end{tabular}

Bron: HBO-Monitor 2006-2010

Opmerking: Alleen de branches waarbinnen ten minste $100 \mathrm{HBO}$-afgestudeerden werkzaam zijn worden weergegeven.

I. Er zijn branches met een nog hoger aandeel afgestudeerden van het HTO, maar het gaat dan om relatief kleine branches. Derhalve worden branches met minder dan Ioo HBO-afgestudeerden hier buiten beschouwing gelaten. 
Uit tabel I.4 blijkt dat het aandeel technici onder werkende HBO'ers het hoogst ligt in de algemene burgerlijke en utiliteitsbouw (en projectontwikkeling). In deze twee branches ligt het aandeel technici onder recent afgestudeerde HBO'ers op zo'n $85 \%$. Andere branches waar een groot deel van alle werkende afgestudeerde HBO'ers een technische opleiding gevolgd heeft zijn de vervaardiging van meet-, regel-, navigatie- en controleapparatuur en van uurwerken, de scheepsbouw, de zee- en kustvaart (vracht-, tank- en sleepvaart) en de architecten, ingenieurs en technisch ontwerp en advies; keuring en controle. In al deze branches hebben circa 8 op de Io recent afgestudeerde HBO'ers een technische opleidingsachtergrond. Andere branches waar technici de dominante groep vormen zijn de vervaardiging van overige machines, apparaten en werktuigen voor specifieke doeleinden en architecten, ingenieurs en technisch ontwerp en advies, de bouw van wegen, spoorwegen en kunstwerken en tot slot de vervaardiging van elektronische componenten en printplaten. In deze branches hebben ruim 7 op de Io werkende HBO'ers een diploma in een technische richting.

Tabel 1.5

Aandeel werkende recent afgestudeerden van het HTO per beroep, 2006-2010

\begin{tabular}{|l|l|r|r|}
\hline & Beroep: & $\%$ HTO & $\%$ HBO totaal \\
\hline 1 & Systeemanalisten & 21,4 & 5,8 \\
\hline 3 & Architecten en bouwkundig projectleiders & 14,0 & 3,1 \\
\hline 4 & Werktuigbouwkundig ontwerpers en hoofden technische dienst & 8,7 & 1,6 \\
\hline 5 & Technisch systeemanalisten & 7,8 & 1,8 \\
\hline 6 & Organisatie-adviseurs & 4,4 & 3,8 \\
\hline 7 & Commercieel medewerkers & 4,2 & 10,6 \\
\hline 8 & Technisch analisten & 3,3 & 0,7 \\
\hline 9 & Technisch-bedrijfsundig medewerkers & 3,2 & 0,7 \\
\hline 10 & Medisch analisten & 3,2 & 0,9 \\
\hline
\end{tabular}

Bron: HBO-Monitor 2006-2010

Van de recent afgestudeerden is verder bekend in welke beroepsgroep zij circa I,5 jaar na afstuderen werkzaam zijn. Uit tabel I.5 blijkt dat de verreweg grootste groep technici in de periode 2006-20I0 werkzaam was als systeemanalist. Ruim I op de 5 werkenden uit de sector techniek heeft gekozen voor een baan als systeemanalist. Daarnaast was een aanzienlijk deel van alle afgestudeerde technici op HBO-niveau werkzaam als architect of bouwkundig projectleider (I4\%). Op de derde plaats van grootste beroepsgroepen staan werktuigbouwkundig ontwerpers en hoofden technische dienst. Ook de functie van technisch systeemanalist blijkt een populair beroep voor afgestudeerden van het HTO. Bijna $8 \%$ van de totale groep werkende recent afgestudeerde HBO'ers met een diploma techniek kiest voor dit beroep. Voor de overige beroepsgroepen wordt door minder dan $5 \%$ van de technici gekozen. De top tien beroepsgroepen gedurende de afgelopen jaren bestaat verder uit de beroepen: organisatie-adviseur, commercieel medewerker, weg- en waterbouwkundig ontwerper en projectleider, technisch analist, technische-bedrijfskundig medewerker en medisch analist. 



\section{De arbeidsmarkt voor afgestudeerden van het HTO}

In hoofdstuk 2 staat de arbeidsmarktintrede van recent afgestudeerden van het Hoger Technisch Onderwijs centraal. In dit hoofdstuk komen verschillende indicatoren aan bod die een indicatie geven over de transitie van het Hoger Technisch Onderwijs naar de arbeidsmarkt over de periode 1998-20I0. Zodoende wordt een beeld verschaft van niet alleen de huidige situatie voor afgestudeerden van het HTO op de arbeidsmarkt, maar ook van de mate waarin die situatie stabiel is, structureel beter of slechter wordt, of gevoelig is voor de conjunctuur. De indicatoren die achtereenvolgens aan bod komen zijn het werkloosheidspercentage, het percentage tijdelijke contracten, zelfstandigen en freelancers, deeltijdwerkers, het niveau en de richting van de huidige functie, het percentage dat de aansluiting tussen onderwijs en arbeidsmarkt als voldoende of goed betiteld, de beloning, de tevredenheid met de huidige baan, het percentage dat spijt heeft van de gevolgde opleiding en tot slot het percentage dat een cursus of bedrijfsopleiding gevolgd heeft. Voor elke indicator wordt de trend voor de recent afgestudeerden van het Hoger Technisch Onderwijs afgezet tegen de trend van de totale groep recent afgestudeerde HBO'ers. De data hebben betrekking op de periode 1998-20I0. Het gaat hierbij om cijfers over het totale Hoger Technisch Onderwijs, wat betekent dat de resultaten voor de specifieke onderliggende opleidingstypen hiervan af kunnen wijken. ${ }^{2}$ In de bijlage zijn voor de periode 2006-20I0 de kernindicatoren werkloosheid, werkzaam in kerndomein, inkomen huidige baan, spijt van de gekozen opleiding en tevredenheid met huidige baan weergegeven voor de afzonderlijke Bachelor-opleidingen van het Hoger Technisch Onderwijs. Deze cijfers worden afgezet tegen het HTO-gemiddelde en het HBO-gemiddelde.

2. Voor meer gedetailleerde informatie op het niveau van afzonderlijke opleidingen over recent afgestudeerden van het Hoger Technisch Onderwijs wordt verwezen naar de HBO-Monitor Kerncijfers Online. Deze informatie is te vinden op www.roa.unimaas.nl/kerncijfers.htm. 
Figuur 2.1

Ontwikkeling werkloosheidspercentage op enquêtemoment, 1998-2010

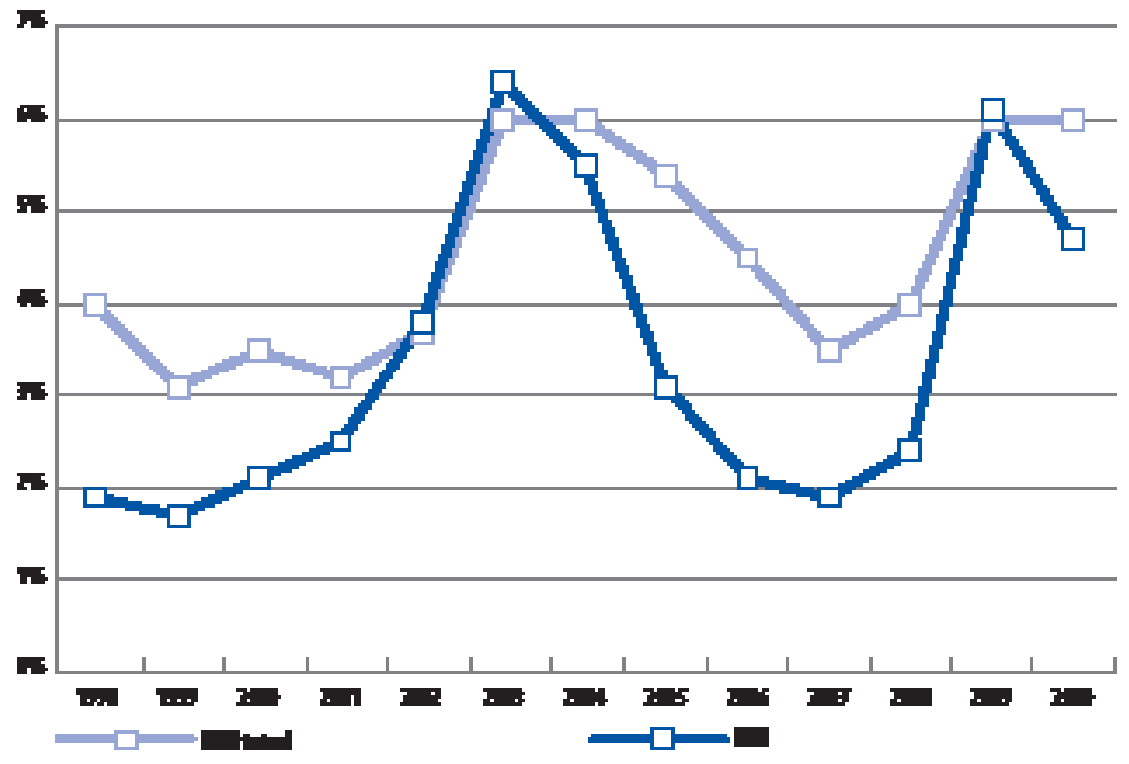

Bron: HBO-Monitor 1998-2010

\section{Werkloosheid}

Afgestudeerden van het Hoger Technisch Onderwijs zijn ongeveer I, 5 jaar na afstuderen minder vaak werkloos dan andere HBO'ers. Het werkloosheidspercentage voor de sector techniek is wel in sterkere mate afhankelijk van de conjunctuur. Als het goed gaat met de economie en er in algemene zin weinig werkloosheid bestaat, is het werkloosheidspercentage onder recent afgestudeerden van het HTO lager dan HBO-gemiddeld. Wanneer de werkloosheid in algemene zin echter snel oploopt, dan worden afgestudeerden van het HTO nog sterker geraakt, zo blijkt uit de pieken in 2003 en 2009 (Figuur 2.I). Hoewel het niveau van de werkloosheid voor de totale groep HBO'ers in 2010 onveranderd hoog is gebleven, zien we de werkloosheid onder afgestudeerden van het HTO weer afnemen. Dit zou er op kunnen wijzen dat de ergste klappen voor $\mathrm{HBO}$-afgestudeerden uit een technische richting voorlopig achter de rug zijn, maar er zijn meer recente data voor nodig om dit met zekerheid vast te kunnen stellen. In 2010 was $4,7 \%$ van de recent afgestudeerden van het HTO werkloos. Onder de totale groep recent afgestudeerde HBO'ers bedroeg het werkloosheidspercentage in dat jaar $6,0 \%$. Zie de bijlage voor de werkloosheidspercentages voor de HTO Bachelor-opleidingen. 


\section{Tijdelijke aanstellingen}

Uit figuur 2.2 blijkt dat het aandeel tijdelijke contracten in sterke mate afhankelijk is van de conjuncturele situatie. Dit geldt iets sterker voor afgestudeerde technici dan voor het $\mathrm{HBO}$-gemiddelde, wat te zien is aan het oplopende verschil ten gunste van de technici in economisch betere tijden (het aandeel technici met een tijdelijke aanstelling daalt harder dan gemiddeld), en het kleiner wordende verschil - dat in de jaren 2002 tot en met 2004 zelfs doorslaat ten nadele van de technici - in economisch slechtere tijden (het aandeel technici met een tijdelijke aanstelling groeit harder dan gemiddeld) . Hoewel minder sterk dan bij de totale groep HBO'ers, is er sinds 1998 sprake van een licht stijgende trend van het aandeel tijdelijke contracten onder recent afgestudeerde techneuten. Evenals in de periode 1998-200I ligt het aandeel tijdelijke contracten sinds 2006 weer onder het $\mathrm{HBO}$-gemiddelde. Dit wijst op een vrij goede arbeidsmarktpositie want dit betekent indirect natuurlijk dat het aandeel vaste contracten boven het $\mathrm{HBO}$-gemiddelde ligt. Tegen het einde van deze periode stijgt, zowel voor de totale groep afgestudeerde HBO'ers als voor de technici, het aandeel tijdelijke contracten sterk als gevolg van de crisis. Sindsdien zijn werkgevers terughoudender geworden in het verstrekken van vaste contracten, waardoor het percentage tijdelijke contracten duidelijk toeneemt.

\section{Figuur 2.2}

Trend tijdelijke aanstellingen (\%), 1998-2010

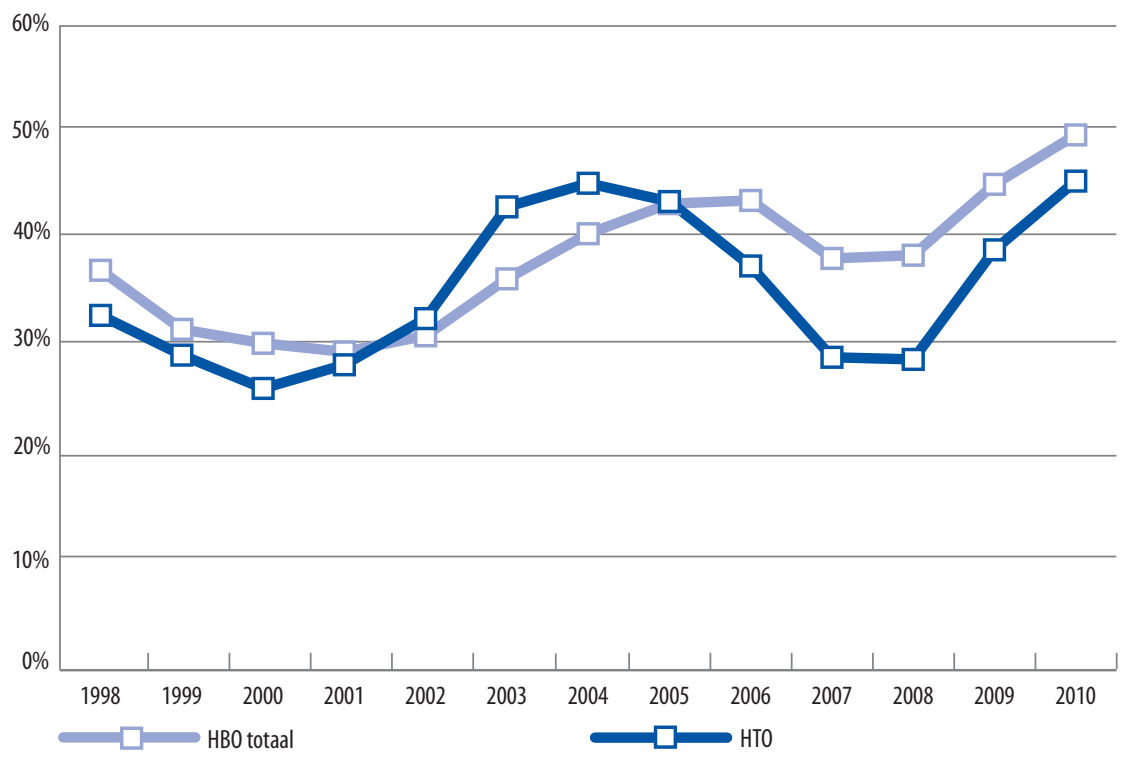

Bron: HBO-Monitor 1998-2010 


\section{Werken als zelfstandige/freelancer}

Figuur 2.3 laat zien dat het aandeel zelfstandigen en freelancers onder technici over de gehele periode relatief laag is. Hoewel minder sterk dan het $\mathrm{HBO}$-gemiddelde, stijgt hun aandeel in de periode 1998-20I0 wel aanzienlijk. Sinds 2006 is het aandeel zelfstandigen en freelancers elk jaar gestegen en vooral in 2010 was er sprake van een relatief grote stijging. Wellicht wordt deze sterke toename veroorzaakt doordat personen, die er door de laagcunjunctuur in 2002-2005 en de economische crisis sinds 2008 niet in slaagden een nieuw contract te bemachtigen, besluiten om voor zichzelf te beginnen. In 2010 bedraagt het percentage zelfstandigen/freelancers onder technici $5,3 \%$. Voor de totale groep HBO'ers ligt dit aandeel met 7,7\% aanzienlijk hoger. Dit wordt veroorzaakt door sectoren als landbouw en gezondheidszorg, maar veel meer nog door taal en cultuur, waar het aandeel zelfstandigen/freelancers veel hoger is. In 20 Io zijn zelfs 6 op de Io recent afgestudeerden van $\mathrm{HBO}$ taal en cultuur met een baan werkzaam als zelfstandige of freelancer. Het gaat hierbij in belangrijke mate om kunstenaars.

Figuur 2.3

Ontwikkeling zelfstandigen/freelancers (\%), 1998-2010

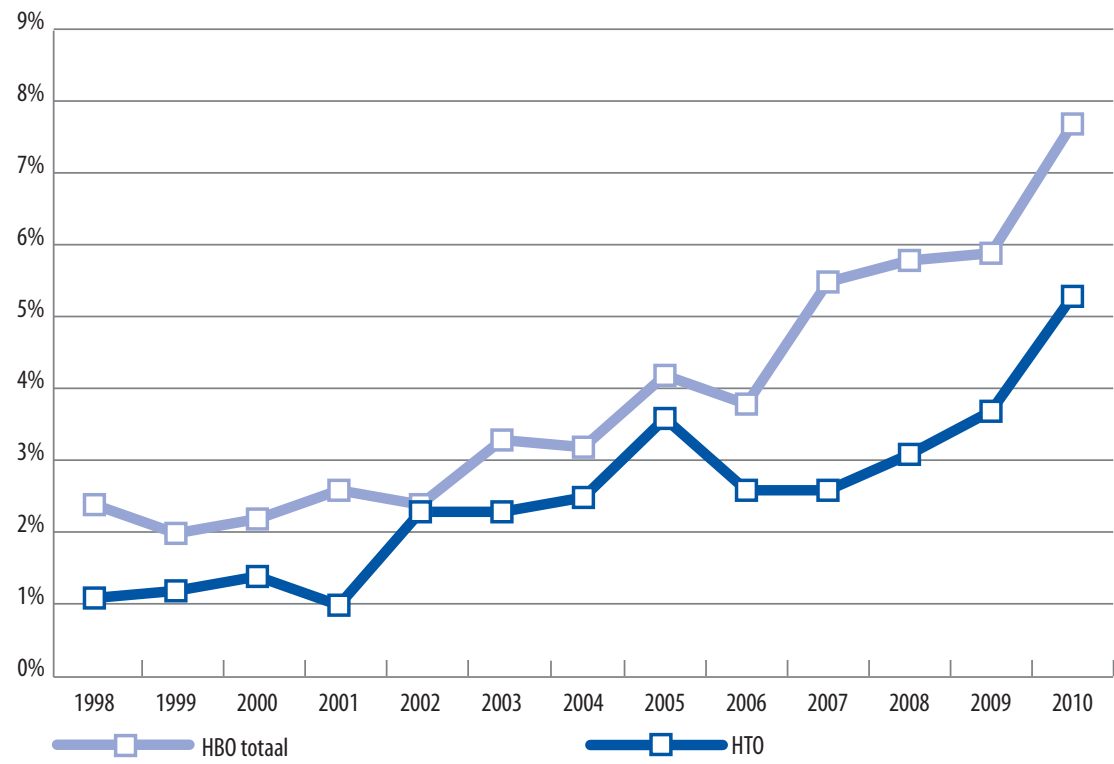

Bron: HBO-Monitor 1998-2010 


\section{Parttime werk}

Ook het percentage parttimers ${ }^{3}$ kan een indicatie geven van de arbeidsmarktpositie van recent afgestudeerden. Een hoog percentage deeltijders kan er op wijzen dat afgestudeerden min of meer gedwongen genoegen moeten nemen met kleine deeltijdbaantjes. Dit hoeft echter niet noodzakelijkerwijs het geval te zijn, want een deel van de parttimers zal er vrijwillig voor kiezen om minder uren te werken. Vaak gaat het hier bijvoorbeeld om vrouwen die slechts enkele dagen per week werken en dit combineren met zorgtaken.

\section{Figuur 2.4}

Ontwikkeling parttime contracten (\%), 1998-2010

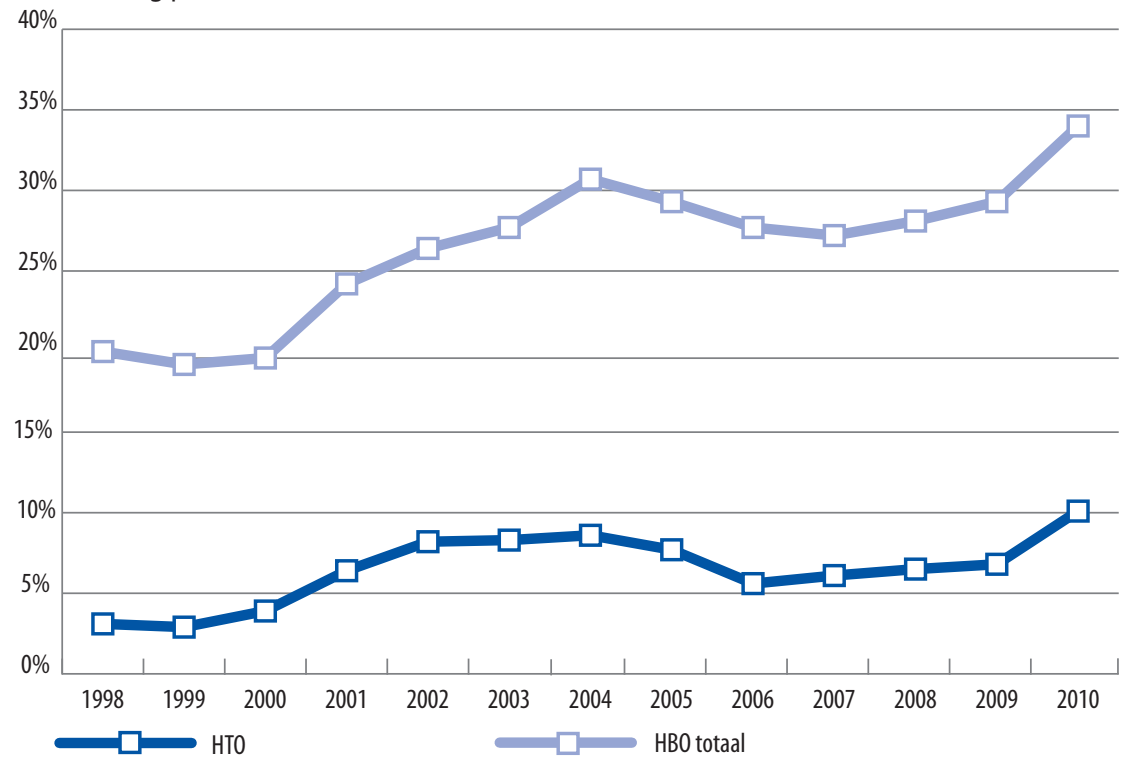

Bron: HBO-Monitor 1998-2010

De technische sector wordt sterk door mannen gedomineerd en deze werken relatief vaak fulltime. Het gemiddelde percentage parttime contracten onder recent afgestudeerde technici $(6,3 \%)$ ligt in deze periode dan ook ver onder het HBO-gemiddelde van $26,5 \%$. Om dit te illustreren is eveneens gekeken naar het aandeel deeltijdwerkers naar geslacht voor HBO techniek en het gehele HBO. Tussen 1998 en 2010 bedraagt het percentage deeltijdwerkers onder recent afgestudeerde mannen van het gehele $\mathrm{HBO}{ }_{13}, 6 \%$, onder vrouwen is dit met $36,7 \%$ duidelijk hoger. Bij afgestudeerden van $\mathrm{HBO}$ techniek wordt in diezelfde periode door een aanzienlijk kleiner deel parttime gewerkt $(6,3 \%)$. Wanneer we voor deze technici kijken naar de verschillen per geslacht, dan blijkt het verschil tussen mannen en vrouwen kleiner te zijn. Van de werkzame

3. Onder parttime werkers wordt hier verstaan: alle werkenden met een contract voor 32 uur of minder per week. 
mannen met een diploma $\mathrm{HBO}$ techniek heeft $5,4 \%$ een parttime functie, terwijl dit bij de vrouwen II\% is. Deze verschillen tussen het $\mathrm{HTO}$ en het $\mathrm{HBO}$-gemiddelde in het aandeel mannen en vrouwen dat parttime werkt verklaart in belangrijke mate het zeer lage percentage deeltijdwerkers onder technici.

Figuur 2.4 laat zien dat het aandeel parttimers voor zowel $\mathrm{HBO}$ techniek als het $\mathrm{HBO}$-gemiddelde afhankelijk is van de conjuncturele situatie. In tegenstelling tot het eerder genoemde vrijwillig in deeltijd werken van vrouwen, wijst deze conjuncturele invloed eerder op een onvrijwillige 'keuze' voor deeltijdwerk. Voor beide groepen geldt daarnaast dat er over deze periode een stijgende trend waarneembaar is. Hoewel het aandeel parttime aanstellingen onder afgestudeerden van het HTO aanmerkelijk lager is dan bij het gehele HBO is dit aandeel onder technici tussen 1998 en 2010 3,3 keer zo groot geworden, terwijl dit aandeel voor het $\mathrm{HBO}$-gemiddelde in die zelfde periode I,7 keer zo groot geworden is.

\section{Niveau en richting van de functie}

Door verdringingseffecten op de arbeidsmarkt is het mogelijk dat recent afgestudeerden noodgedwongen genoegen moeten nemen met een functie die onder hun niveau is of die buiten hun vakgebied is. Gedurende de periode 1998-20I0 werken technici met een $\mathrm{HBO}$-diploma relatief weinig onder hun niveau. Van deze groep werkt $\mathrm{I} 5, \mathrm{I} \%$ onder zijn of haar niveau, terwijl dit voor het totale $\mathrm{HBO} 20, \mathrm{I} \%$ is. Ook wat betreft het percentage buiten het vakgebied werkenden doen recent afgestudeerden van $\mathrm{HBO}$ techniek het in deze periode beter dan gemiddeld. Terwijl het $\mathrm{HBO}$-gemiddelde $2 \mathrm{I}, 4 \%$ bedraagt, werkt van de technici $17,0 \%$ buiten de opleidingsrichting.

Als het door de werkgever voor de functie vereiste niveau gecombineerd wordt met de vereiste opleidingsrichting kan geconcludeerd worden of de recent afgestudeerden werkzaam zijn in hun kerndomein. Met een baan in het kerndomein wordt bedoeld dat iemand een baan heeft op minimaal zijn opleidingsniveau, in dit geval HBO, en tegelijkertijd in dezelfde richting als de voltooide opleidingsrichting.

Recent afgestudeerden werken vlak na afstuderen relatief vaak in hun eigen kerndomein. Iets minder dan driekwart van hen $(72,9 \%)$ heeft tussen 1998 en 2010 een baan op minimaal HBO-niveau én in de techniek (figuur 2.5). Bij de totale groep recent afgestudeerde HBO'ers werkt zo'n twee derde in het eigen kerndomein. In afzonderlijke sectoren varieert dit overigens van $54,0 \%$ voor $\mathrm{HBO}$ gedrag en maatschappij tot $87,0 \%$ voor $\mathrm{HBO}$ onderwijs. Onder technici is vooral de groep die zowel onder het niveau als buiten de opleidingsrichting werkt kleiner dan gemiddeld, maar er werkt eveneens een iets kleiner deel alleen onder het niveau of alleen buiten de richting. Dit wijst op een goede arbeidsmarktintrede van afgestudeerde technici. In de bijlage zijn de resultaten met betrekking tot het percentage dat binnen het kerndomein werkzaam is weergegeven per HTO Bachelor-opleiding. 


\section{Figuur 2.5}

Vereist niveau en vereiste richting van de baan, 1998-2010

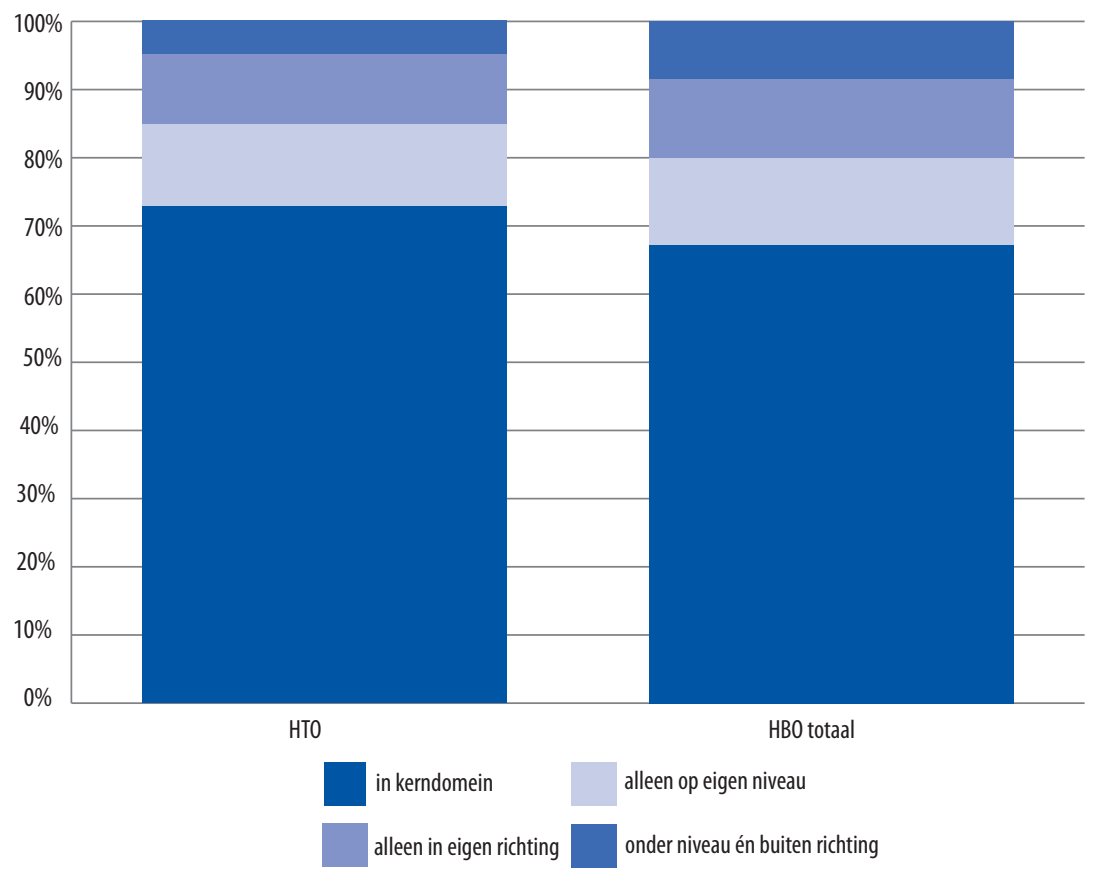

Bron: HBO-Monitor 1998-2010

Veel van de overige baankenmerken van afgestudeerden worden in belangrijke mate bepaald door het feit of zij al dan niet binnen hun kerndomein werken. Ter illustratie wordt in tabel 2.4 een overzicht gegeven van enkele baankenmerken voor afgestudeerden wiens huidige functie zowel qua als niveau richting aansluit bij de gevolgde HBO-opleiding. Dit wordt vergeleken met afgestudeerden die respectievelijk alleen onder hun niveau werken, alleen buiten hun richting werken en zowel onder hun niveau als buiten hun richting werken.

Uit tabel 2.4 blijkt dat afgestudeerden die minimaal op het eigen niveau, maar juist buiten hun eigen vakgebied werken, vaak zelfstandige of freelancer zijn. Degenen die in hun kerndomein werken hoeven het minst vaak genoegen te nemen met een tijdelijk contract. Bovendien oordelen zij in lijn der verwachting het vaakst positief over de aansluiting tussen opleiding en werk, ontvangen zij het hoogste reële bruto uurloon en zijn zij het vaakst tevreden met hun baan. Degenen die zowel onder hun niveau als buiten hun richting werken hebben het vaakst een tijdelijk contract, een deeltijdbaan, oordelen het minst gunstig over de aansluiting, verdienen het minst en zijn het minst tevreden met hun baan. Recent afgestudeerden die minimaal op het eigen niveau werken, maar die niet in hun eigen richting werken, hebben minder vaak een tijdelijk contract, verdienen meer en zijn vaker tevreden met de huidige baan dan degenen die 
wel in hun eigen richting werken maar niet op hun eigen niveau. Laatstgenoemden werken juist minder in deeltijd en oordelen positiever over de aansluiting tussen opleiding en werk.

Tabel 2.4

Baankenmerken naar werken in/buiten kerndomein, 2006-2010

\begin{tabular}{|c|c|c|c|c|c|c|}
\hline & $\begin{array}{r}\text { zelfstandige/ } \\
\text { freelancer } \\
(\%)\end{array}$ & $\begin{array}{r}\text { tijdelijke } \\
\text { aanstelling } \\
(\%)\end{array}$ & $\begin{array}{l}\text { parttime } \\
\text { werk (\%) }\end{array}$ & $\begin{array}{r}\text { aansluiting } \\
\text { opleiding-werk } \\
(\%)\end{array}$ & $\begin{array}{r}\text { gem reëel } \\
\text { uurloon } \\
(€)\end{array}$ & $\begin{array}{r}\text { tevreden met } \\
\text { baan (\%) }\end{array}$ \\
\hline \multicolumn{7}{|l|}{ HTO } \\
\hline in kerndomein & 2,4 & 34,8 & 6,0 & 81,9 & 14,37 & 75,0 \\
\hline alleen op eigen niveau & 7,9 & 35,0 & 10,5 & 62,2 & 14,29 & 70,8 \\
\hline alleen in eigen richting & 2,2 & 39,0 & 4,8 & 72,9 & 13,66 & 61,3 \\
\hline onder niveau én buiten richting & 5,5 & 50,8 & 24,1 & 40,2 & 12,33 & 40,8 \\
\hline totaal & 3,0 & 35,7 & 6,9 & 77,8 & 14,24 & 72,4 \\
\hline \multicolumn{7}{|l|}{ HBO totaal } \\
\hline in kerndomein & 5,2 & 41,7 & 28,6 & 84,4 & 14,08 & 74,4 \\
\hline alleen op eigen niveau & 6,3 & 44,3 & 17,5 & 58,8 & 13,72 & 61,9 \\
\hline alleen in eigen richting & 3,4 & 43,6 & 41,5 & 69,8 & 12,67 & 51,5 \\
\hline onder niveau én buiten richting & 3,7 & 54,7 & 38,0 & 32,8 & 11,33 & 33,1 \\
\hline totaal & 5,1 & 43,1 & 29,2 & 76,1 & 13,69 & 67,6 \\
\hline
\end{tabular}

Bron: HBO-Monitor 2006-2010

Er is eveneens gekeken hoe het percentage in het kerndomein werkenden zich ontwikkeld heeft over de tijd (I998-20I0). Figuur 2.6 geeft voor zowel afgestudeerden van de sector techniek als de totale groep afgestudeerde HBO'ers weer welk deel van hen binnen hun kerndomein werkzaam is. Technici werken gedurende de hele periode vaker dan gemiddeld binnen hun kerndomein. $\mathrm{Na} 2005$ stijgt dit percentage voor zowel HBO totaal als voor HBO techniek. Ongeveer 8 op de Io recent afgestudeerde technici werkt dan in een aan techniek gerelateerde functie. Dit blijft enkele jaren min of meer stabiel, waarna er in 20 Io een daling plaatsvindt tot driekwart van de technici. Onder de totale groep afgestudeerde HBO'ers is de negatieve trend reeds enkele jaren eerder ingetreden. 
Figuur 2.6

Ontwikkeling werkenden in kerndomein (\%), 1998-2010

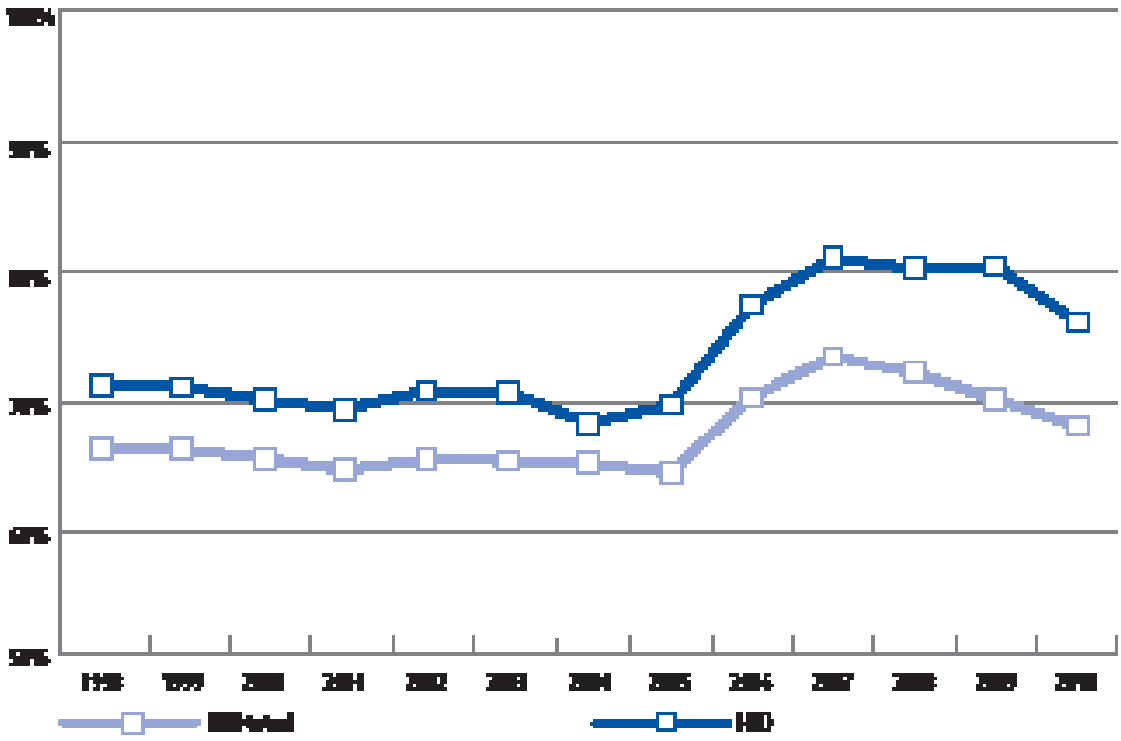

Bron: HBO-Monitor 1998-2010

Aansluiting opleiding-werk

Figuur 2.7 laat zien hoe de aansluiting tussen de gevolgde opleiding en de baan ervaren is. De figuur geeft weer welk deel deze aansluiting als goed of voldoende heeft ervaren. De ontwikkeling van deze indicator vertoont voor technici een zelfde verloop als voor de totale groep afgestudeerde HBO'ers. Zowel voor technici als het $\mathrm{HBO}$-gemiddelde geldt dat recent afgestudeerden na 2002 minder positief oordelen over deze aansluiting. In algemene zin vinden 8 op de Io recent afgestudeerden dat de aansluiting goed of voldoende is. 
Figuur 2.7

Ontwikkeling aansluiting tussen opleiding en werk is goed/voldoende (\%), 1998-2010

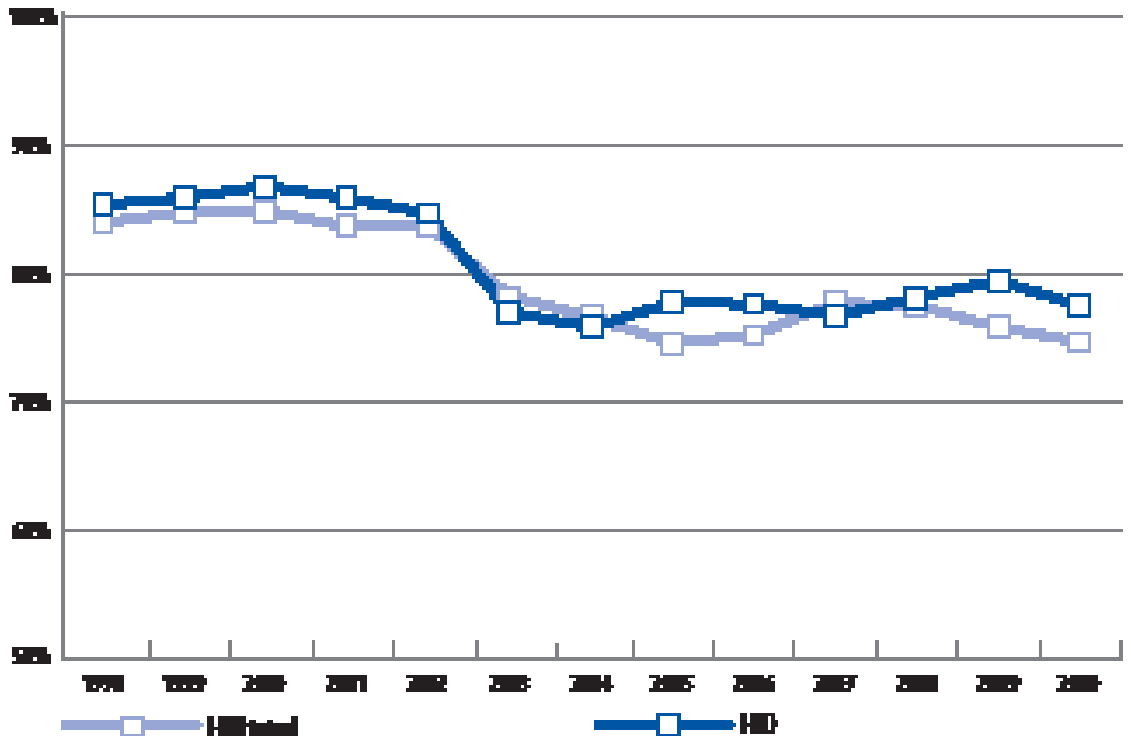

Bron: HBO-Monitor 1998-2010

Inkomen huidige baan

De startsalarissen bieden eveneens een indicatie van de arbeidsmarktpositie van recent afgestudeerden. Hieruit blijkt immers de waarde die werkgevers toekennen aan hun kwaliteiten. Aan de ontwikkeling van het reële bruto uurloon van recent afgestudeerden is duidelijk het conjuncturele verloop terug te zien (figuur 2.8). Hierbij is rekening gehouden met de jaarlijkse inflatiecorrectie van het CBS. Tussen 1998 en 2006 benadert het reële bruto uurloon van technici de beloning van de totale groep recent afgestudeerden van het HBO. Vooral voor technici is er sprake van een sterke stijging van de reële beloning vanaf 2005. Als gevolg van de crisis dalen de reële lonen van zowel technici als de totale groep HBO'ers na 2008 wel aanzienlijk, maar ze dalen niet zo ver als het niveau voor 2005. Ook tijdens de recente crisis is de reële beloning van technici duidelijk hoger dan het $\mathrm{HBO}$-gemiddelde. Dit lijkt een indicatie te zijn dat er structureel iets veranderd. In 2008 was dit verschil het grootst. Bij eenzelfde fulltime betrekking in 2010 verdienen technici reëel zo'n Ioo euro per maand meer dan het $\mathrm{HBO}$-gemiddelde. Dit houdt mogelijkerwijs verband met de verwachte tekorten aan technici waardoor werkgevers bereid kunnen zijn om een hoger salaris te betalen om zodoende de op handen zijnde tekorten aan technici het hoofd te kunnen bieden. Zie de bijlage voor de gemiddelde bruto uurlonen per HTO Bachelor-opleiding. 
Figuur 2.8

Ontwikkeling reële bruto uurlonen $(€)$, 1998-2010

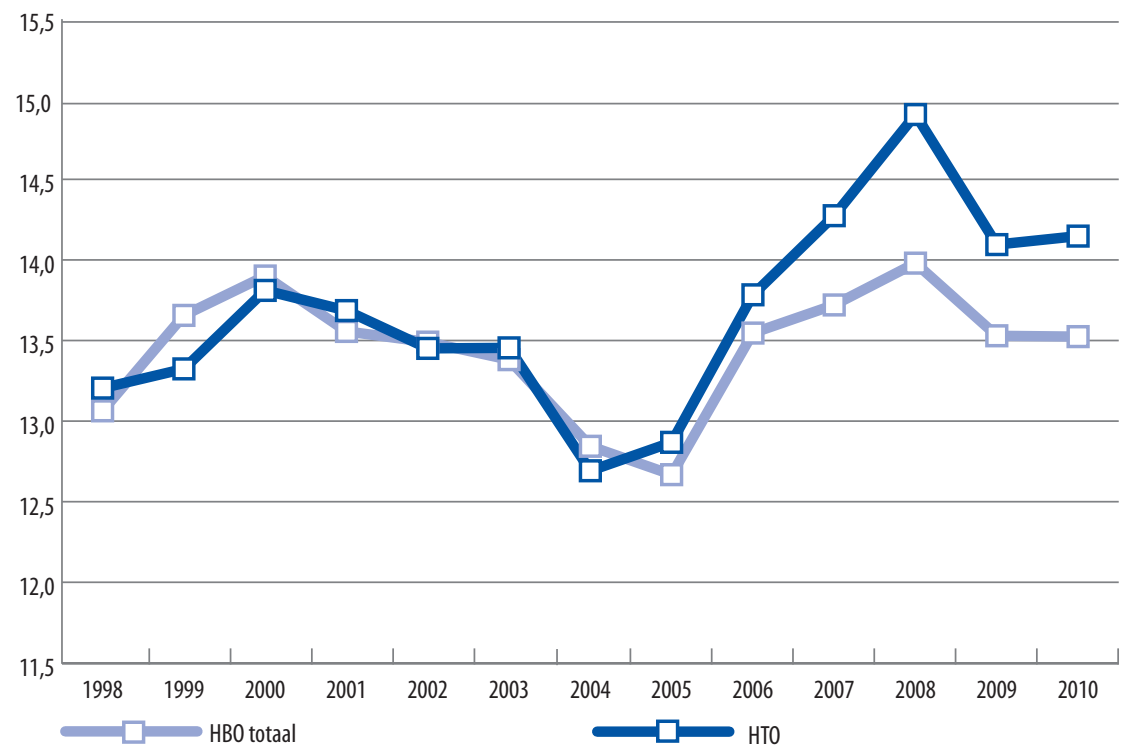

Bron: HBO-Monitor 1998-2010

\section{Tevredenheid met huidige baan}

Recent afgestudeerde technici blijken I, 5 jaar na afstuderen relatief tevreden met hun functie, zoals blijkt uit figuur 2.9. Hoewel de baantevredenheid van technici in de periode 2003-20IO niet heel veel afwijkt van het $\mathrm{HBO}$-gemiddelde, kan wel geconcludeerd worden dat deze sinds 2005 bovengemiddeld is. Van alle werkende technici met een HBO-diploma zijn 7 op de Io tevreden of zeer tevreden met de huidige baan. Tegen het einde van de periode daalt de baantevredenheid enigszins. Dit wordt wellicht deels veroorzaakt door de economische crisis, waardoor het aandeel werkenden in het kerndomein en het bruto uurloon enigszins daalt en het aandeel parttimers enigszins stijgt. Zie de bijlage voor de tevredenheidspercentages per HTO Bachelor-opleiding 


\section{Figuur 2.9}

Ontwikkeling (zeer) tevreden met huidige functie (\%), 2003-2010 4

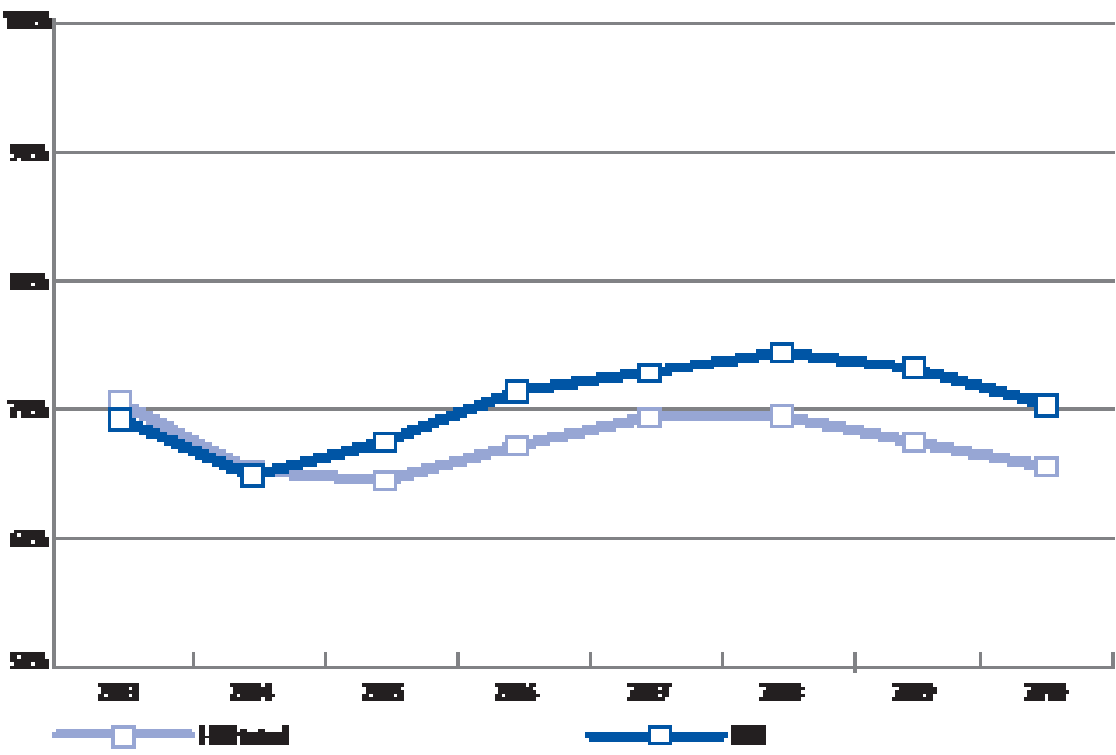

Bron: HBO-Monitor 2003-2010

\section{Spijt van de gekozen opleiding}

Aan de afgestudeerden is eveneens gevraagd of zij, achteraf bezien, opnieuw voor de eerder gevolgde HBO-opleiding zouden kiezen. Figuur 2.IO geeft voor de periode I998-20I0 weer welk deel van hen achteraf spijt heeft van de gevolgde opleiding. Hoewel de verschillen gering zijn, hebben technici iets minder spijt van de eerder gemaakte opleidingskeuze dan de totale groep HBO-afgestudeerden. Positief is verder dat er voor de sector techniek een licht dalende trend waarneembaar is, wat betekent dat afgestudeerde technici terugkijkend op de eerder gevolgde opleiding minder vaak spijt zeggen te hebben.

4. De variabele tevredenheid met de huidige baan is niet beschikbaar voor eerdere jaren.

Enquêtevraag: Hoe tevreden bent u met uw huidige functie (I 'zeer ontevreden' tot en met 5 'zeer tevreden'. Vermeld is het percentage van antwoordcategorie 4 en 5. 
Figuur 2.10

Achteraf gezien spijt van de gevolgde opleiding (\%), 1998-2010

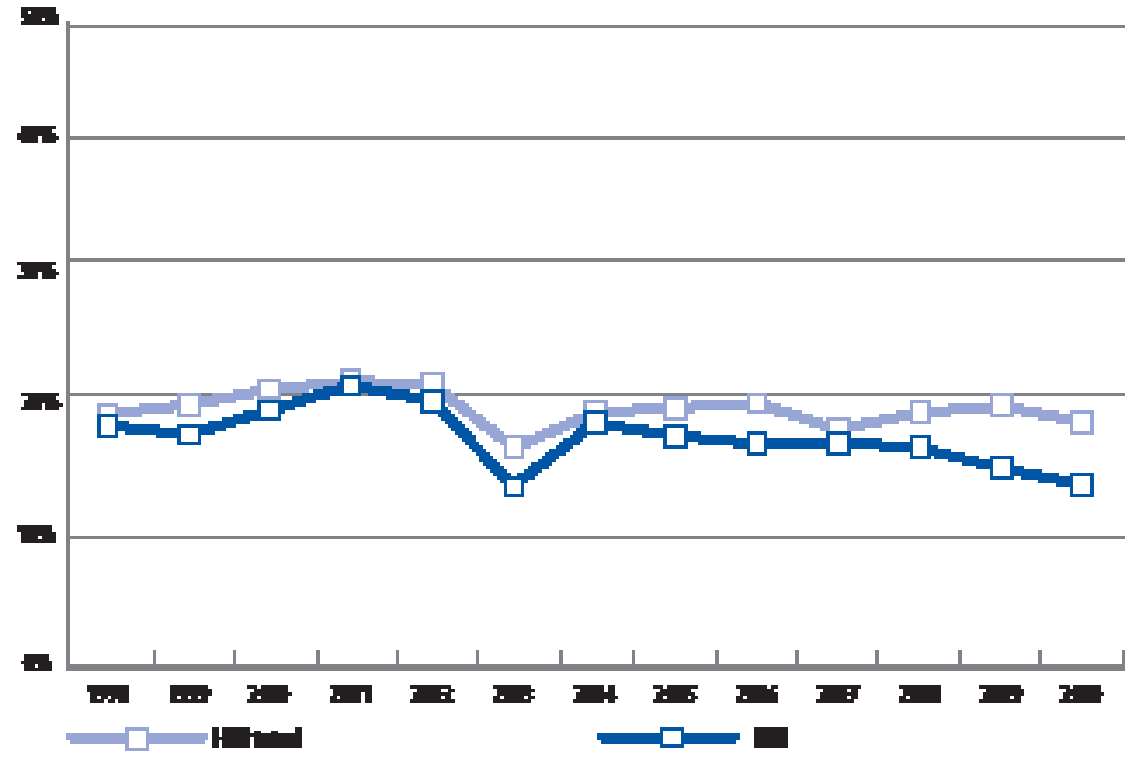

Bron: HBO-Monitor 1998-2010

\section{Cursus of bijscholing gevolgd}

Tegenwoordig wordt alom onderschreven dat de ontwikkeling van menselijk kapitaal niet op dient te houden bij het verlaten van de schoolbanken. Aangezien het belang van continue ontwikkeling en het concept van Leven Lang Leren de laatste jaren toeneemt, wordt in figuur 2.II gekeken of hier vroeg in de beroepsloopbaan al aandacht aan besteed wordt. De figuur geeft het percentage recent afgestudeerden weer dat I, 5 jaar na afstuderen reeds de mogelijkheid heeft gekregen om een cursus of bedrijfsopleiding te volgen. Hoewel het aandeel technici dat vlak na het betreden van de arbeidsmarkt reeds een cursus of bedrijfsopleiding gevolgd heeft gedurende deze periode behoorlijk fluctueert, ligt dit aandeel in elk afzonderlijk jaar boven het HBO-gemiddelde. Gemiddeld geeft ruim de helft van de afgestudeerde technici $(54,0 \%)$ aan additionele scholing te hebben gehad, tegenover minder dan de helft bij de totale groep HBO-afgestudeerden $(46,7 \%)$. Daarmee scoort techniek op deze indicator over de hele periode bezien het best van alle zeven sectoren op HBO-niveau. Wel moet hierbij worden aangetekend dat er in 2010 een forse daling van dit percentage heeft plaatsgevonden onder technici, waardoor het $\mathrm{HBO}$-gemiddelde in zicht komt. 
HOOFDSTUK 2

Figuur 2.11

Cursus of bedrijfsopleiding gevolgd na HBO-opleiding (\%), 1998-2010

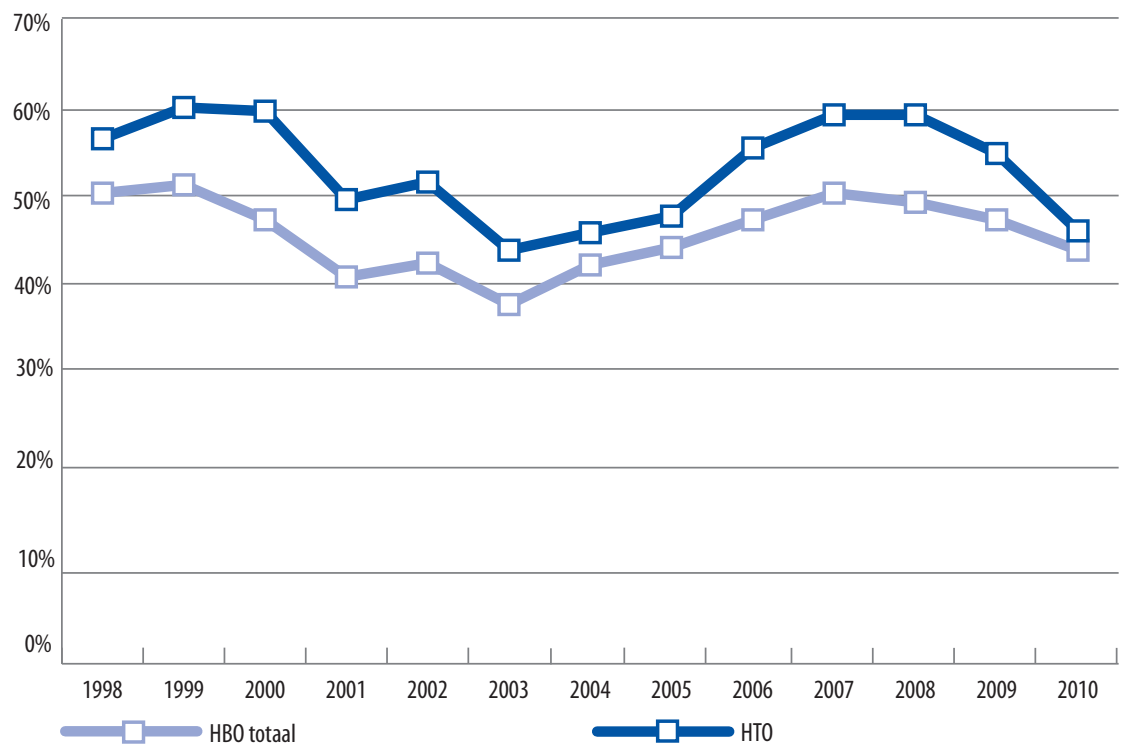

Bron: HBO-Monitor 1998-2010 


\section{Arbeidsmarktperspectieven}

In hoofdstuk 3 staan de verwachte arbeidsmarktperspectieven van tot 2016 voor HTO afgestudeerden centraal. Tweejaarlijks biedt ROA een overzicht van de huidige en toekomstige arbeidsmarktontwikkelingen. Een belangrijk onderdeel hierin zijn de arbeidsmarktperspectieven van schoolverlaters. Het toekomstig arbeidsmarktperspectief voor afgestudeerden met een specifieke opleidingsachtergrond geeft de verhouding weer tussen vraag en aanbod op de arbeidsmarkt in de prognoseperiode 20II20I6. De vraag- en aanbodprognoses zijn gebaseerd op de actuele arbeidsmarktpositie van afgestudeerden van een bepaald opleidingstype. Als het arbeidsmarktperspectief van een opleiding slecht is, betekent dit dat er de komende jaren meer aanbod is van nieuwkomers op de arbeidsmarkt met een dergelijk diploma dan dat er baanopeningen voor deze groep ontstaan. Hierdoor zal hun arbeidsmarktpositie verslechteren. Deze verslechtering kan tot uiting komen in een hogere werkloosheid, maar door aanpassingsprocessen op de arbeidsmarkt kan de verslechtering van de arbeidsmarktsituatie ook leiden tot het moeten aanvaarden van banen op een lager niveau, tegen een lagere beloning en tot meer tijdelijke contracten. Aan de andere kant zal een goed perspectief voor afgestudeerden met een specifieke opleidingsachtergrond niet alleen resulteren in een grotere kans op werk, maar eveneens in een verbeterde positie op andere punten.

Het toekomstig arbeidsmarktperspectief per opleidingstype wordt bepaald door middel van de Indicator Toekomstig Arbeidsmarktperspectief (ITA). 5 Deze is gedefinieerd als de verhouding tussen de verwachte arbeidsmarktinstroom van afgestudeerden en het aantal kortdurig werklozen enerzijds, en de verwachte baanopeningen en de passieve substitutievraag anderzijds. Naarmate de waarde van de indicator hoger is wordt het arbeidsmarktperspectief slechter. De bijbehorende kwalitatieve typering van de arbeidsmarktperspectieven luidt achtereenvolgens zeer goed, goed, redelijk, matig of slecht.

De toekomstige arbeidsmarktperspectieven naar opleiding tot 2016 laten zien dat de vooruitzichten voor afgestudeerde technici de komende jaren op alle opleidingsniveaus rooskleurig zijn. Zowel op VMBO-, MBO-, HBO- als WO-niveau wordt namelijk verwacht dat technici goede perspectieven zullen hebben.

5. Zie voor meer informatie over de arbeidsmarktperspectieven van schoolverlaters op de middellange termijn: ROA (20IIb), De arbeidsmarkt naar opleiding en beroep tot 20I6, ROA-R-20II/8, Maastricht University. 
Tabel 3.I geeft een overzicht van de ITA voor de sector HBO techniek als zodanig, alsook voor de acht onderscheiden onderliggende opleidingstypen binnen $\mathrm{HBO}$ techniek: laboratorium, bouwkunde, civiele techniek, werktuigbouwkunde, elektrotechniek, informatica, chemische technologie en vervoer en logistiek. Uit de tabel blijkt dat afgestudeerde technici van het $\mathrm{HBO}$ op de middellange termijn goede arbeidsmarktperspectieven hebben (ITA: 0,96). Dit wordt veroorzaakt door een gemiddeld aantal nieuwe baanopeningen voor afgestudeerden van $\mathrm{HBO}$ techniek tegenover een lager dan gemiddeld aantal instromers op de arbeidsmarkt. Het aantal baanopeningen voor afgestudeerden van $\mathrm{HBO}$ techniek in de periode 20II-20I6, gemeten als het gemiddelde jaarlijkse percentage van de werkgelegenheid in 2010 , bedraagt $4, \mathrm{I} \%$. In diezelfde periode wordt een gemiddelde jaarlijkse instroom op de arbeidsmarkt verwacht van $2,8 \%$ voor afgestudeerden met een diploma $\mathrm{HBO}$ techniek.

Binnen $\mathrm{HBO}$ techniek worden op de middellange termijn de beste arbeidsmarktperspectieven verwacht voor afgestudeerden van $\mathrm{HBO}$ laboratorium en $\mathrm{HBO}$ chemische technologie. Voor deze beide opleidingstypen zijn de vooruitzichten zelfs zeer goed te noemen. De rooskleurige perspectieven voor afgestudeerden van HBO laboratorium worden veroorzaakt door een zeer hoog aantal nieuwe baanopeningen tegenover een lage arbeidsmarktinstroom. Deze baanopeningen voor laboranten worden op hun beurt veroorzaakt door een hoge uitbreidingsvraag (bovenop het huidige personeelsbestand zijn extra werknemers nodig) in combinatie met een zeer hoge vervangingsvraag (nieuwe werknemers zijn nodig om oudere werknemers die met pensioen gaan te vervangen). Bij $\mathrm{HBO}$ chemische technologie zijn de vooruitzichten ook zeer goed, maar hier ligt met name de grote uitbreidingsvraag aan ten grondslag.

Tabel 3.1

Indicator Toekomstige Arbeidsmarktperspectieven (ITA) voor afgestudeerden van het Hoger Technisch Onderwijs tot 2016, per opleidingstype

\begin{tabular}{|l|r|r|}
\hline Opleiding: & Indicator & Typering \\
\hline HBO techniek: & 0,96 & goed \\
\hline HBO laboratorium & 0,81 & zeer goed \\
\hline HBO bouwkunde & 1,01 & redelijk \\
\hline HBO civiele techniek & 0,88 & goed \\
\hline HBO werktuigbouwkunde & 0,89 & goed \\
\hline HBO elektrotechniek & 0,90 & goed \\
\hline HBO informatica & 1,21 & slecht \\
\hline HBO chemische technologie & 0,84 & zeer goed \\
\hline HBO vervoer en logistiek & 0,88 & goed \\
\hline
\end{tabular}

Bron: ROA (AIS)

Naast de zeer goede perspectieven voor afgestudeerde technici van de hiervoor besproken opleidingstypen, zijn er nog meerder opleidingstypen in de $\mathrm{HBO}$-sector techniek waarvoor goede perspectieven verwacht worden. Tot 2016 zullen afgestudeerden van de HBO-opleidingen civiele techniek, werktuigbouwkunde, elektro- 
techniek en vervoer en logistiek doorgaans eenvoudig een geschikte baan vinden. Bij al deze opleidingstypen is sprake van een gemiddelde uitbreidingsvraag. De vervangingsvraag is daarentegen hoog voor civiele techniek en werktuigbouwkunde. Voor vervoer en logistiek is de vervangingsvraag zelfs zeer hoog en dit verklaart het grote aantal baanopeningen voor afgestudeerden van genoemde opleidingstypen. Vaak kan hierbij gewezen worden op de hoge gemiddelde leeftijd van arbeidskrachten. Deze zullen binnen afzienbare tijd vervangen moeten worden doordat zij met pensioen gaan. Bij werktuigbouwkunde wordt dit effect nog versterkt door de lage verwachte instroom die hier tegenover staat. Ook voor elektrotechniek wordt op de middellange termijn een lage instroom verwacht en doordat het aantal baanopeningen voor dit opleidingstype gemiddeld is, wordt er toch een goed arbeidsmarktperspectief voor personen met deze opleidingsachtergrond verwacht.

Dat de arbeidsmarktperspectieven niet voor alle technische afgestudeerden met een $\mathrm{HBO}$-opleiding goed of zeer goed zijn, blijkt uit de indicator voor $\mathrm{HBO}$ bouwkunde en in het bijzonder HBO informatica. Hoewel bij HBO bouwkunde sprake is van een gemiddeld aantal verwachte baanopeningen, wordt hiervoor tegelijkertijd een gemiddelde instroom verwacht. Dit resulteert in de bijbehorende typering als redelijke arbeidsmarktperspectieven. Zijn de vooruitzichten tot 2016 voor $\mathrm{HBO}$ bouwkunde nog redelijk te noemen, voor HBO informatica zijn deze ronduit slecht. Dit komt door het lage verwachte aantal baanopeningen in de komende jaren, veroorzaakt door een gemiddelde uitbreidingsvraag in combinatie met een lage vervangingsvraag. Hier staat juist een hoog aantal verwachte nieuwe instromers met deze opleidingsachtergrond tegenover, waardoor er volgens de prognoses meer aanbod dan vraag zal ontstaan. 



\section{Vereiste competenties voor afgestudeerden van het HTO}

In hoofdstuk 2 werd een korte schets gegeven van de arbeidsmarkt voor afgestudeerden van het HTO in het verleden en het heden, en in hoofdstuk 3 werden prognoses gepresenteerd van de verwachte ontwikkelingen van de werkgelegenheid in de toekomst. Deze vooral kwantitatieve ontwikkelingen zijn interessant en belangrijk, maar zeggen weinig of niets over hoe het werk in de toekomst in kwalitatieve zin eruit zal zien. In dit hoofdstuk wordt een korte schets gegeven van enkele belangrijke ontwikkelingen in de sector en komt aan bod hoe het onderwijsveld op de te verwachten trends kan inspelen bij het opleiden van toekomstige arbeidskrachten voor de technische sector. De focus ligt hierbij op de competenties waar het onderwijsveld zich op moet gaan richten. In paragraaf 4.I worden enkele algemene en sectorspecifieke trends en ontwikkelingen besproken. In paragraaf $4.2 \mathrm{komt} \mathrm{het} \mathrm{vereiste} \mathrm{competentieniveau} \mathrm{aan}$ bod van recent afgestudeerden die werkzaam zijn in hun kerndomein. Bovendien wordt hier besproken of bepaalde competenties door de jaren heen belangrijker zijn geworden. In paragraaf 4.2 komen vervolgens de ervaren competentietekorten aan bod.

\subsection{Trends en ontwikkelingen}

Voorbeelden van algemene sector overstijgende trends zijn onder meer demografische ontwikkelingen zoals vergrijzing en ontgroening, voortschrijdende technologische ontwikkelingen, de toenemende invloed van internet en ICT, heterogeniteit van de samenleving, individualisering van mondialisering, klimaatproblematiek en de verschuiving van het economisch zwaartepunt en de daarmee gepaard gaande internationale machtsverhoudingen. Deze raken alle in meer of mindere mate de gehele technische sector.

Al deze trends kunnen op hun beurt vragen om specifieke competenties van de arbeidskrachten die werkzaam zijn in een sector, en dus indirect van invloed zijn op de inrichting van het Hoger Onderwijs. Deze ontwikkelingen leiden er immers toe dat bepaalde competenties belangrijker worden, terwijl andere competenties in de toekomst mogelijkerwijs juist minder van afgestudeerden gevraagd zullen worden.

Op basis van de literatuur kunnen er vier trends worden gedefinieerd die specifiek spelen in de technische sector: kenniscrisis, technologische ontwikkelingen, toene- 
mende concurrentie en stijgende grondstofprijzen. Hieronder worden deze trends kort toegelicht.

\section{Kenniscrisis}

De technische sector heeft te kampen met een hoge gemiddelde leeftijd. Dit betekent dat een groot deel van de werknemers binnen afzienbare tijd met pensioen gaat en dus vervangen moet worden. In combinatie met de lage instroom van jonge technici zal dit leiden tot een 'kenniscrisis' in de technische sector. Volgens ondernemersorganisatie van technologische industrie FME-CWM is dit de belangrijkste bedreiging voor de technologische industrie (FD, I2 januari 20I2).

\section{Technologische ontwikkelingen}

Technologische ontwikkelingen volgen elkaar in hoog tempo op. Door ontwikkelingen als ontgroening en vergrijzing zullen naar verwachting arbeidsintensieve sectoren als de zorg, het onderwijs en de publieke sector steeds vaker arbeidsbesparende technieken gaan implementeren. Door de snelle toename van (de vraag naar) technologische ontwikkelingen betekent stilstand, meer nog dan in andere sectoren, achteruitgang. Dit vraagt om continue innovatie en ook om netwerksamenwerking (Rabobank, 20I2). Ook vraagt dit om vakkennis en kerncompetenties die continu 'up to date' zijn.

\section{Toenemende concurrentie}

Door de grote concurrentie binnen de technische sector wordt er van technische medewerkers in toenemende mate gevraagd dat zij naast vaktechnische competenties beschikken over klantgerichte competenties (flexibiliteit, probleemoplossend vermogen, snelle levertijd) (Arbeidsmarktmonitor Metalektro, 20II).

\section{Stijgende grondstofprijzen}

De voortdurende dreiging van stijgende grondstof- en energieprijzen zorgt ervoor dat industriële bedrijven met hun prijzen omhoog moeten gaan of dat hun eigen winstmarges kleiner worden. Een trend die Rabobank waarneemt in de industrie is dan ook het streven naar zogenoemde ketenoptimalisatie. Hierbij werken partijen samen op het gebied van productie of ontwikkeling om zo hun positie te versterken (Rabobank, 20I2).

\subsection{Vereist niveau competenties}

Gebruikmakend van de HBO-Monitor wordt in deze paragraaf ingegaan op de competentieniveaus die vereist worden voor afgestudeerden van het HTOen boven- 
dien of deze significant belangrijker zijn geworden over de tijd. Aan de afgestudeerden die kort na afstuderen betaald werk hebben in hun kerndomein is gevraagd om voor 23 verschillende competenties een inschatting te geven van zowel het vereiste niveau in de functie die zij op dat moment hebben als het niveau dat zij zichzelf op dat moment toedichten. De afgestudeerden kunnen in beide gevallen een keuze maken op basis van een vijfpuntsschaal die oploopt van I 'niveau is matig' tot 5 'niveau is uitmuntend'.

Tabel 4.I geeft voor de periode 2004-20I0 weer hoe afgestudeerden het vereiste niveau voor elk van de afzonderlijke competenties beoordelen. Hierbij wordt de groep afgestudeerde technici vergeleken met de totale groep afgestudeerde HBO'ers in deze periode. De data voor de totale groep pas afgestudeerde HBO'ers zijn herwogen om een zo eerlijk mogelijke vergelijking te waarborgen. Tevens wordt weergegeven of er sprake is van een significante trend in het vereiste niveau van elke competentie. Zo wordt duidelijk welke competenties belangrijker zijn geworden en welke juist minder van afgestudeerden worden gevraagd. De trend geeft de gemiddelde jaarlijkse toe- of afname weer en wordt alleen weergegeven wanneer deze statistisch significant is. ${ }^{6}$

\section{Vereiste competentieniveaus}

Zoals blijkt uit tabel 4.I, is het vereiste niveau voor technici qua competenties het hoogst wat betreft het zelfstandig kunnen uitvoeren van werkzaamheden. Op een schaal van I tot 5 geven afgestudeerden gemiddeld aan dat het vereiste niveau van deze competentie in hun baan 4,2 bedraagt. De top drie van competenties waarvoor een hoog niveau wordt vereist van afgestudeerde technici wordt vervolledigd door de competenties logisch redeneren en aan anderen duidelijk kunnen maken wat men bedoelt. Afgestudeerden beoordelen het vereiste niveau van beide competenties gemiddeld als 4,O. Andere competenties die technici in belangrijke mate dienen te bezitten zijn: problemen en kansen signaleren, goed onder druk kunnen functioneren, nieuw dingen leren, productief samenwerken, informatie vergaren en verbanden leggen. Afgestudeerden met een diploma in de techniek geven aan dat het vereiste niveau daarentegen het laagst is voor het communiceren in een buitenlandse taal $(3,0)$. Ook wat betreft de kennis van andere vakgebieden $(3,2)$ en capaciteiten van anderen aanspreken $(3,5)$ wordt een relatief gezien laag niveau van deze afgestudeerden vereist.

6. De trends zijn berekend door middel van 23 afzonderlijke regressieanalyses waarbij het vereiste competentieniveau de afhankelijke variabele is. Telkens is het effect van het aantal jaren verstreken vanaf $2004(2004=0, \ldots 2010=6)$ berekend op het vereist niveau van de verschillende competenties. Om het effect zo zuiver mogelijk te houden zijn eventuele verschuivingen in de compositie van de sector naar opleiding of hogeschool uitgebannen, door in de analyse een dummy op te nemen voor elke opleiding en school die in de sector is vertegenwoordigd. 
Tabel 4.1

Vereist competentieniveau, 2004-2010*

\begin{tabular}{|c|c|c|c|c|}
\hline & $\mathrm{HT}$ & & HBO & \\
\hline & gem. & trend & gem. & trend \\
\hline Kennis van: & & & & \\
\hline eigen vakgebied & 3,7 & 0,016 & 3,8 & 0,012 \\
\hline andere vakgebieden & 3,2 & n.s. & 3,3 & n.s. \\
\hline Vermogen om: & & & & \\
\hline vakkennis in praktijk toe te passen & 3,8 & 0,017 & 3,9 & 0,010 \\
\hline informatie- \& communicatietechnologie te gebruiken & 3,8 & n.s. & 3,6 & 0,021 \\
\hline in buitenlandse talen te communiceren & 3,0 & 0,021 & 2,5 & n.s. \\
\hline informatie te vergaren & 3,9 & 0,013 & 3,9 & n.s. \\
\hline problemen en kansen te signaleren & 3,9 & 0,018 & 4,1 & 0,011 \\
\hline verbanden te leggen tussen verschillende zaken & 3,9 & 0,018 & 4,0 & 0,011 \\
\hline hoofd- van bijzaken te onderscheiden & 3,8 & n.s. & 3,9 & n.s. \\
\hline logisch te redeneren & 4,0 & 0,012 & 4,0 & n.s. \\
\hline conform budget, planning of richtlijnen te werken & 3,7 & 0,012 & 3,6 & 0,014 \\
\hline onder druk goed te functioneren & 3,9 & n.s. & 4,0 & n.s. \\
\hline knopen door te hakken & 3,6 & 0,017 & 3,7 & 0,012 \\
\hline nieuwe ideeën en oplossingen te bedenken & 3,8 & 0,018 & 3,9 & n.s. \\
\hline nieuwe dingen te leren & 3,9 & 0,012 & 4,0 & n.s. \\
\hline aan anderen duidelijk te maken wat men bedoelt & 4,0 & 0,012 & 4,2 & n.s. \\
\hline productief met anderen samen te werken & 3,9 & 0,010 & 4,0 & n.s. \\
\hline capaciteiten van anderen aan te spreken & 3,5 & 0,016 & 3,7 & 0,017 \\
\hline zelfstandig de werkzaamheden uit te voeren & 4,2 & n.s. & 4,3 & n.s. \\
\hline Bereidheid om: & & & & \\
\hline de nek uit te steken & 3,6 & 0,010 & 3,8 & 0,011 \\
\hline eigen en andermans ideeën ter discussie te stellen & 3,7 & 0,020 & 3,8 & 0,010 \\
\hline voor eigen standpunt op te komen & 3,7 & 0,013 & 3,8 & n.s. \\
\hline begrip te tonen voor andere standpunten & 3,8 & 0,016 & 3,9 & 0,009 \\
\hline
\end{tabular}

* Gemiddeld antwoord van afgestudeerden op 5-puntschaal (1'matig t/m 5'uitmuntend') Bron: HBO-Monitor 2004-2010

Trends worden alleen weergegeven wanneer deze significant zijn op minimaal 5\%-niveau. Data zijn herwogen voor HBO totaal.

Hoe verhoudt het vereiste niveau van deze competenties dat van technici gevraagd wordt zich tot dat van de gehele groep HBO-afgestudeerden? Van alle 23 verschillende onderzochte competenties ligt het vereiste niveau van afgestudeerden uit de sector techniek duidelijk lager dan het HBO-gemiddelde. Dit is namelijk het geval bij I7 competenties. Tegelijkertijd betekent dit dat het vereiste niveau van technici bij slechts drie competenties even hoog, en bij drie andere hoger ligt dan bij de totale groep afgestudeerde HBO'ers. Een mogelijke verklaring hiervoor zou kunnen zijn dat werkgevers in de afgelopen periode door de lage instroom van technici op de arbeidsmarkt al blij waren als ze voldoende afgestudeerde technici konden aantrekken om 
openstaande vacatures op te vullen. Hoewel het vereiste niveau van de afzonderlijke competenties onder technici niet veel lager is dan het $\mathrm{HBO}$-gemiddelde, zou dit er toch op kunnen wijzen dat werkgevers wellicht toch enige concessies doen om maar genoeg geïnteresseerden in de techniek aan te trekken. Werkgevers kunnen er voor kiezen om deze afgestudeerden zelf op te gaan leiden tot het gewenste niveau. Eerder zagen we reeds dat afgestudeerde technici relatief vaak cursussen gedaan hebben vlak na afstuderen. Deze zogenaamde upgrading zou deze theorie kunnen ondersteunen.

In vergelijking met het $\mathrm{HBO}$-gemiddelde ligt het vereiste competentieniveau bij technici relatief laag voor de bereidheid om de nek uit te steken, capaciteiten van anderen aanspreken en anderen duidelijk maken wat men bedoelt. Van de competenties waarvan juist een hoger dan gemiddeld niveau wordt verwacht bij technici springt met name het communiceren in een buitenlandse taal eruit. Ondanks dat dit bij technici de competentie is waarvoor het relatief gezien laagste niveau vereist wordt $(3,0)$, is dit vereiste niveau beduidend hoger dan bij de totale groep HBO'ers. Ook worden technici in vergelijking met andere HBO'ers geacht om meer conform richtlijnen te kunnen werken en informatie- en communicatietechnologie te kunnen gebruiken.

\section{Trends in vereiste competentieniveaus}

Dat er dynamiek zit in het vereiste competentieniveau waarover recent afgestudeerde technici moeten beschikken blijkt wel uit het feit dat het vereiste niveau van I8 van de 23 tussen 2004 en 2010 significant gestegen is. In tabel 4.I wordt de ontwikkeling van het vereiste competentieniveau weergegeven in de kolom 'trend'. Hoewel bij technici het vereiste niveau van het communiceren in een buitenlandse taal het laagst is van alle onderscheiden competenties is het vereiste niveau van deze competentie wel het sterkst toegenomen in deze periode. Ook dienen afgestudeerde technici in toenemende mate ideeën van anderen en van zichzelf ter discussie durven te stellen. Andere competenties waarvoor tegenwoordig een hoger niveau van technici vereist wordt zijn bijvoorbeeld het signaleren van problemen en kansen, het leggen van verbanden tussen verschillende zaken en het bedenken van nieuwe ideeën en oplossingen. Dit zou te maken kunnen hebben met de snel op elkaar volgende technologische ontwikkelingen en toenemende concurrentie die in de vorige paragraaf zijn beschreven. Opvallend is verder dat er geen sprake is van een significante trend voor de competentie waarvoor technici aangeven dat het hoogste niveau van hen vereist wordt (i.e. zelfstandig kunnen werken). Dit betekent dat deze competentie weliswaar in belangrijke mate van technici gevraagd wordt, maar dat deze tussen 2004 en 2010 niet belangrijker geworden is.

Ook voor de totale groep HBO'ers is geanalyseerd of er tussen 2004 en 20 Io ontwikkelingen waarneembaar zijn in het vereiste niveau van competenties. Hierbij is weer de eerder toegelichte herweging toegepast om te voorkomen dat er significante trends gevonden worden, enkel door de grote omvang van de totale groep recent afgestudeerde HBO'ers. Waren er bij technici slechts vijf competenties waar geen significante 
veranderingen in het niveau van competenties hebben plaatsgevonden, bij $\mathrm{HBO}$ totaal zijn er twaalf competenties waarvoor het vereiste niveau niet significant gestegen is. Bovendien is het zo dat de stijgingen in het vereiste niveau van de competenties die significant zijn, kleiner zijn dan de trends in het vereiste niveau voor technici. Dit wijst nogmaals op de dynamiek in de sector techniek. Bij de totale groep recent afgestudeerden van het $\mathrm{HBO}$ nemen daarnaast andere competenties in belang toe dan bij de groep technici. Bij HBO totaal stijgt in deze periode het vereiste niveau van het ICT-gebruik het snelst. Ook worden afgestudeerde HBO'ers tegenwoordig meer dan vroeger in staat geacht om capaciteiten van anderen aan te spreken. De overige significante ontwikkelingen voor de gehele groep $\mathrm{HBO}$ 'ers zijn relatief klein van aard.

\subsection{Competentietekorten}

Naast het vereiste competentieniveau van recent afgestudeerden die in hun kerndomein werken is ook van hen bekend hoe zij hun eigen niveau inschatten wat betreft deze competenties. Door beide met elkaar te vergelijken ontstaat een verschilscore die inzicht geeft in eventuele competentietekorten of -overschotten. Wanneer het eigen niveau lager is dan het vereiste niveau is er sprake van een tekort. Is het eigen niveau daarentegen hoger dan het vereiste niveau, dan is er juist sprake van een overschot. Hierbij is het belangrijk om te benadrukken dat een (klein) tekort niet noodzakelijkerwijs een probleem hoeft te betekenen. Een klein tekort bij een bepaalde competentie kan immers betekenen dat afgestudeerden het als een uitdaging ervaren om dit punt te verbeteren. Indien afgestudeerden geen tekort ervaren, dan zou het kunnen dat zij geen noodzaak zien in het blijven ontwikkelen van die specifieke competentie. De tekorten die hier besproken worden moeten dus eerder in het kader van een signaalfunctie geïnterpreteerd worden, dan dat zij meteen als groot probleem gezien worden.

Tabel 4.2 geeft de competentietekorten weer die recent afgestudeerde technici ervaren die in hun kerndomein werkzaam zijn in de periode 2004-20Io en vergelijkt deze met het $\mathrm{HBO}$-gemiddelde. Tevens wordt voor beide de trend weergegeven zodat duidelijk wordt voor welke competenties de tekorten in de voorbije periode significant zijn toegenomen. Hierbij is gecontroleerd voor veranderingen in de compositie van opleidingen en hogescholen. Dit om veranderingen in de competentietekorten zo zuiver mogelijk weer te geven. 
Tabel 4.2

Ervaren tekorten op het gebied van competenties, 2004-2010 (\%)

\begin{tabular}{|c|c|c|c|c|}
\hline & $\begin{array}{l}\text { HTO } \\
\text { gem. }\end{array}$ & trend & $\begin{array}{r}\text { HBO totaal } \\
\text { gem. }\end{array}$ & trend \\
\hline \multicolumn{5}{|l|}{ Kennis van: } \\
\hline eigen vakgebied & 33,2 & 0,849 & 36,5 & n.s. \\
\hline andere vakgebieden & 26,1 & n.s. & 25,8 & n.s. \\
\hline \multicolumn{5}{|l|}{ Vermogen om: } \\
\hline vakkennis in praktijk toe te passen & 24,4 & 0,860 & 28,6 & n.s. \\
\hline informatie- \& communicatietechnologie te gebruiken & 15,0 & 0,639 & 15,9 & 0,657 \\
\hline in buitenlandse talen te communiceren & 21,2 & 0,500 & 14,3 & 0,502 \\
\hline informatie te vergaren & 18,7 & 0,614 & 17,6 & 0,510 \\
\hline problemen en kansen te signaleren & 29,5 & 0,986 & 33,2 & 0,711 \\
\hline verbanden te leggen tussen verschillende zaken & 24,4 & 0,855 & 27,3 & 0,679 \\
\hline hoofd-van bijzaken te onderscheiden & 27,7 & n.s. & 27,5 & n.s. \\
\hline logisch te redeneren & 18,2 & 0,517 & 18,3 & 0,559 \\
\hline conform budget, planning of richtlijnen te werken & 34,3 & n.s. & 27,3 & n.s. \\
\hline onder druk goed te functioneren & 25,2 & n.s. & 28,6 & n.s. \\
\hline knopen door te hakken & 28,4 & 0,845 & 29,1 & 0,738 \\
\hline nieuwe ideeën en oplossingen te bedenken & 27,2 & 0,972 & 28,9 & n.s. \\
\hline nieuwe dingen te leren & 14,2 & 0,689 & 15,3 & 0,636 \\
\hline aan anderen duidelijk te maken wat men bedoelt & 34,2 & 1,017 & 33,3 & 0,607 \\
\hline productief met anderen samen te werken & 14,9 & 0,492 & 17,4 & 0,697 \\
\hline capaciteiten van anderen aan te spreken & 23,1 & n.s. & 28,3 & n.s. \\
\hline zelfstandig de werkzaamheden uit te voeren & 19,8 & 0,799 & 21,1 & 0,615 \\
\hline \multicolumn{5}{|l|}{ Bereidheid om: } \\
\hline de nek uit te steken & 15,6 & 0,425 & 17,2 & n.s. \\
\hline eigen en andermans ideeën ter discussie te stellen & 18,7 & 0,921 & 24,1 & 0,726 \\
\hline voor eigen standpunt op te komen & 21,2 & 1,209 & 26,5 & 0,695 \\
\hline begrip te tonen voor andere standpunten & 14,7 & n.s. & 15,9 & 0,457 \\
\hline
\end{tabular}

* Eigen niveau is lager dan vereist niveau

Bron: HBO-Monitor 2004-2010

Trends worden alleen weergegeven wanneer deze significant zijn op minimaal 5\%-niveau.

Data voor HBO totaal zijn herwogen om een eerlijke vergelijking te waarborgen.

\section{Ervaren competentietekorten}

De eerste kolom van de tabel geeft voor elk van de 23 verschillende competenties weer welk deel van de in het kerndomein werkende technici een tekort ervaart op die specifieke competentie. Zo geeft bijvoorbeeld I op de 3 afgestudeerde technici $(33,2 \%)$ aan dat de kennis van het eigen vakgebied lager is dan het door de werkgever vereiste niveau in de huidige functie. Dit zou te maken kunnen hebben met het eerder genoemde matige vereiste niveau, waarschijnlijk als gevolg van het tekort aan technici. Technici ervaren eveneens vaak tekorten met betrekking tot het werken conform 
budget, planning of richtlijnen en het aan anderen duidelijk maken wat men bedoelt. Voor beide competenties geeft ruim een derde aan dat het eigen niveau onder het vereiste niveau is. Tegelijkertijd geven bijna 3 op de Io technici aan dat zij in het begin van hun loopbaan een competentietekort ervaren met betrekking tot het signaleren van problemen en kansen, het onderscheiden van hoofd- en bijzaken, kopen doorhakken, en het bedenken van nieuwe ideeën en oplossingen. Bij andere competenties ervaren recent afgestudeerde technici juist minder vaak tekorten en geeft een veel kleiner deel aan dat het eigen niveau lager is dan het vereiste niveau. Het gaat dan met name om het vermogen om nieuwe dingen te leren, het productief met anderen samen te werken, ICT te gebruiken en begrip te tonen voor andere standpunten. Minder dan $15 \%$ van de technici die tussen 2004 en 2010 in hun kerndomein werken geeft bij genoemde competenties aan dat het eigen niveau lager is dan het vereiste niveau.

Ook voor de totale groep HBO'ers is geanalyseerd wat de grootste tekorten zijn en welke ontwikkelingen er de voorbije jaren zoal spelen. Bij de totale groep $\mathrm{HBO}$-afgestudeerden wordt het grootste tekort ervaren op het gebied van de kennis van het eigen vakgebied. 36,5\% van alle recent afgestudeerde HBO'ers vindt het eigen niveau qua kennis lager dan het voor de functie vereiste niveau. Dit is iets meer dan bij de technici. Een andere competentie waarvoor vaak tekorten gerapporteerd worden is, evenals bij technici, aan anderen duidelijk maken wat men bedoelt. De gehele groep HBO'ers ervaart nog iets vaker een competentietekort met betrekking tot het signaleren van problemen en kansen. Daarmee zijn dit de drie vaakst genoemde competenties waarvoor een tekort bestaat bij de totale groep HBO'ers. Bij HBO totaal zijn de tekorten het kleinst voor het leren van nieuwe dingen en het communiceren in een buitenlandse taal.

Er kan eveneens gekeken worden naar de relatieve verschillen tussen technici en andere HBO'ers. In algemene zin doet de sector techniek het goed, want bij I7 van de 23 competenties ervaren zij minder tekorten dan het HBO-gemiddeld. In het bijzonder ervaren technici minder dan gemiddeld tekorten bij het ter discussie stellen van eigen en andermans ideeën ( $5,4 \%$-punt), het aanspreken van capaciteiten van anderen en het opkomen voor het eigen standpunt (beide -5,3\%-punt). Wat zijn juist competenties waarop technici relatief vaak een tekort ervaren als het gaat om het eigen niveau? Opvallend is dat de competentie waarvoor technici het vaakst aangaven dat hun niveau onder het vereiste niveau ligt, het werken conform budget, planning of richtlijnen $(34,3 \%)$, beduidend minder wordt genoemd door de totale groep HBO'ers. Van de technici ervaart 7,0\%-punt meer tekorten op deze competentie. In vergelijking met het $\mathrm{HBO}$-gemiddelde zijn er onder technici bovendien behoorlijke tekorten bij het communiceren in een buitenlandse taal. Op deze competentie ligt het eigen niveau van technici eveneens aanzienlijk vaker (6,8\%-punt) onder het voor de functie vereiste niveau dan bij de totale groep HBO'ers 


\section{Trends in competentietekorten}

Onder technici is er een stijgende trend in de tekorten waarneembaar voor I7 van de 23 competenties. Van de eerder genoemde 18 competenties die significant belangrijker zijn geworden voor afgestudeerde technici, zijn er 15 waarvan bovendien het ervaren tekort significant stijgt. Dit geeft aan dat er Is competenties zijn waarbij het hoger onderwijs de ontwikkelingen in de vereiste niveaus voor recent afgestudeerde technici niet heeft kunnen bijbenen. Competentietekorten bij technici zijn tussen 2004 en 2OIo vooral sterk toegenomen als het gaat om het opkomen voor het eigen standpunt en aan anderen duidelijk maken wat men bedoelt. Maar aan het begin van de beroepsloopbaan zien technici de afgelopen jaren hun eigen niveau eveneens steeds verder achterblijven ten opzichte van het voor de functie vereiste niveau bij de competenties: problemen en kansen signaleren, nieuwe ideeën en oplossingen bedenken, en eigen en andermans ideeën ter discussie stellen. Verder is het opvallend dat het werken conform budget, planning of richtlijnen weliswaar door de grootste groep technici als tekort genoemd werd, maar dat dit tekort in deze periode niet verder is opgelopen.

Bij de totale groep HBO'ers is er in iets mindere mate sprake van significant oplopende competentietekorten in de afgelopen jaren. Bij $\mathrm{HBO}$ totaal is het tekort bij I4 competenties significant opgelopen, terwijl dit onder technici bij 17 competenties het geval was. Bij de totale groep HBO'ers stijgen de tekorten in de meeste gevallen bovendien minder hard dan bij technici. De totale groep HBO'ers is de afgelopen jaren steeds minder in staat om aan het begin van hun carrière knopen door te hakken dan noodzakelijk geacht in hun functie. Andere competenties die HBO'ers in het algemeen steeds minder lijken te beheersen zijn problemen en kansen signaleren en eigen en andermans ideeën ter discussie stellen. 



\section{Conclusie}

Vanwege de groei van de technische sector maar de beperkte instroom van studenten in bètastudies, is er een dreigend tekort aan hoog opgeleid technisch personeel. Dit is een groot risico voor de sector, maar het leidt er wel toe dat afgestudeerden van het $\mathrm{HTO}$ op alle arbeidsmarktindicatoren beter scoren dan het HBO-gemiddelde. Ze zijn o.a. minder vaak werkloos, hebben vaker een vast contract, werken vaker binnen hun kerndomein, hebben een hoger salaris, zijn tevredener over hun functie en hebben minder vaak spijt van de gekozen opleiding. Ook zijn de arbeidsmarktindicatoren van de HTO afgestudeerden minder gevoelig voor laagconjunctuur dan het $\mathrm{HBO}$-gemiddelde.

Voor de totale groep HTO afgestudeerden, en voor de meeste opleidingstypen binnen het HTO, zijn de toekomstige arbeidsmarktperspectieven dan ook goed te noemen, en voor sommige opleidingstypen zelfs zeer goed. Alleen voor HBO informatica zijn de perspectieven slecht, en voor HBO bouwkunde redelijk.

Op basis van algemene en sectorspecifieke trends is er gekeken naar de vereiste competenties voor HTO afgestudeerden. In de periode 2004-20IO is het vereiste niveau van I8 van de 23 gedefinieerde competenties significant gestegen:

- Kennis van eigen vakgebied

- Vermogen om vakkennis in praktijk toe te passen

- Vermogen om in buitenlandse talen te communiceren

- Vermogen om informatie te vergaren

- Vermogen om problemen en kansen te signaleren

- Vermogen om verbanden te leggen tussen verschillende zaken

- Vermogen om logisch te redeneren

- Vermogen om conform budget, planning of richtlijnen te werken

- Vermogen om knopen door te hakken

- Vermogen om nieuwe ideeën en oplossingen te bedenken

- Vermogen om nieuwe dingen te leren

- Vermogen om aan anderen duidelijk te maken wat men bedoelt

- Vermogen om productief met anderen samen te werken

- Vermogen om capaciteiten van anderen aan te spreken

- Bereidheid om de nek uit te steken

- Bereidheid om eigen en andermans ideeën ter discussie te stellen 
- Bereidheid om voor eigen standpunt op te komen

- Bereidheid om begrip te tonen voor andere standupnten

Ervaren competentietekorten geven aan waar hogescholen in de toekomst meer aandacht aan zouden kunnen besteden bij de inhoud van het technisch onderwijs. De analyses wijzen uit dat zo'n I5 tot $34 \%$ van de afgestudeerde HTO'ers competentietekorten ervaart bij bovenstaande belangrijker wordende competenties. Van de afgestudeerde HTO'ers ervaart in de periode 2004-20IO 34\% een competentietekort in het vermogen om conform budget, planning of richtlijnen te werken, en tevens ervaart $34 \%$ een competentietekort in het vermogen om aan anderen duidelijk te maken wat men bedoelt.

Alleen bij de competenties vermogen om conform budget, planning of richtlijnen te werken, vermogen om capaciteiten van anderen aan te spreken en bereidheid om begrip te tonen voor andere standpunten, was geen significante stijging in het ervaren tekort te zien. Bij de overige is belangrijker wordende competenties werd bovendien een groter wordend tekort ervaren. 


\section{Literatuur}

Financieel Dagblad (12 januari 2012) Groeiend tekort aan technisch specialisten [elektronische versie] http://fd.nl/Print/krant/Pagina/Ondernemen/652261-1201/groeiend-tekort-aantechnisch-specialisten_bron_fd_krant, 12-01-2012.

HBO-raad (2012), Inschrijvingen: absolute aantallen.. http://cijfers.hbo-raad.nl/QvAJAXZfc/ opendoc.htm?document=2_Inschrijvingen.qvw\&host=Local\&anonymous=true, 10-092012.

Ministerie van Onderwijs, Cultuur en Wetenschap (2011), Hoofdlijnenakkoord OCW - HBOraad, Den Haag: OCW.

Platform Bèta Techniek (2010), Technomonitor 2010, Den Haag.

Rabobank (2012), Cijfers \& trends, Branche-informatie: industrie, 36e jaargang, maart 2012.

ROA (2011a), Arbeidsmarktmonitor Metalektro, Editie 2011, Maastricht University.

ROA (2011b), De arbeidsmarkt naar opleiding en beroep tot 2016, Maastricht University. 



\section{Bijlage: Kernindicatoren voor HTO Bachelor-opleidingen}

Tabel B1

Vijf kernindicatoren voor HTO Bachelor-opleidingen, 2006-2010

\begin{tabular}{|c|c|c|c|c|c|c|}
\hline HTO Bachelor-opleiding & Werkloosheid & $\begin{array}{r}\text { Werkzaam in } \\
\text { kerndomein } \\
\%\end{array}$ & $\begin{array}{r}\text { gem. } \\
\text { Bruto } \\
\text { uurloon } \\
€\end{array}$ & $\begin{array}{r}\begin{array}{r}\text { Spijt } \\
\text { opleiding }\end{array} \\
\%\end{array}$ & $\begin{array}{r}\text { Tevreden } \\
\text { met } \\
\text { functie } \\
\%\end{array}$ & Aantal \\
\hline A0T Techniek & 1,1 & 63,0 & 15,28 & 13,9 & 66,9 & 93 \\
\hline Aquatische ecotechnologie & 0,0 & 87,8 & 13,14 & 12,8 & 92,3 & 25 \\
\hline Aquatische Ecotechnologie & 6,7 & 65,4 & 12,94 & 23,1 & 74,1 & 21 \\
\hline Autotechniek & 2,8 & 75,9 & 14,14 & 19,4 & 63,5 & 358 \\
\hline Bio-informatica & $x$ & $x$ & $x$ & $x$ & $x$ & 18 \\
\hline Biologie en Medisch Laboratoriumonderzoek & 1,9 & 85,0 & 13,10 & 13,0 & 73,2 & 840 \\
\hline Biometrie & 7,9 & 80,0 & 12,78 & 35,3 & 65,7 & 23 \\
\hline Bouwkunde & 3,7 & 80,7 & 13,79 & 12,4 & 75,9 & 1559 \\
\hline Bouwmanagement en Vastgoed & 2,4 & 82,9 & 16,09 & 32,0 & 67,1 & 24 \\
\hline Bouwtechnische Bedrijfskunde & 5,2 & 79,3 & 14,38 & 13,2 & 80,3 & 146 \\
\hline Business Engineering & 0,0 & 66,7 & 28,78 & 25,0 & 86,5 & 27 \\
\hline Chemie & 5,1 & 79,3 & 13,27 & 14,6 & 68,2 & 374 \\
\hline Chemische Technologie & 5,9 & 81,4 & 16,48 & 10,1 & 75,7 & 168 \\
\hline Civiele Techniek & 1,5 & 87,1 & 14,48 & 9,4 & 78,1 & 735 \\
\hline Commercieel Ingenieur & $x$ & $x$ & $x$ & $\mathrm{x}$ & $x$ & 12 \\
\hline Communication \& Multimedia Design & 8,4 & 65,1 & 13,10 & 29,2 & 67,7 & 451 \\
\hline Elektrotechniek & 2,5 & 82,9 & 13,79 & 16,8 & 74,1 & 1196 \\
\hline Embedded Systems Engineering & $x$ & $x$ & $x$ & $\mathrm{x}$ & $x$ & 6 \\
\hline Geodesie & 0,0 & 67,7 & 19,68 & 19,2 & 71,0 & 41 \\
\hline Gezondheidszorg Technologie & 5,2 & 52,7 & 14,66 & 19,6 & 82,1 & 27 \\
\hline Grafimediatechnologie & 3,8 & 71,0 & 13,22 & 43,5 & 69,6 & 135 \\
\hline Hogere Informatica & 0,5 & 85,7 & 14,69 & 17,5 & 83,3 & 165 \\
\hline Human Technolgy & 9,3 & 49,4 & 14,15 & 54,2 & 71,0 & 101 \\
\hline Hydrografie & $x$ & $x$ & $x$ & $x$ & $x$ & 9 \\
\hline Industrieel Produdukt Ontwerpen & 7 & 77,9 & 13,21 & 16,5 & 67,8 & 295 \\
\hline Industriële Automatisering & 2,5 & 85,7 & 14,69 & 13,7 & 71,4 & 47 \\
\hline Informatica & 2,3 & 82,5 & 14,85 & 16,8 & 72,7 & 1211 \\
\hline Informatica en Informatiekunde & 1,9 & 77,5 & 14,98 & 37,9 & 68,5 & 238 \\
\hline Logistiek en Technische Vervoerskunde & 4,0 & 70,6 & 14,09 & 11,8 & 69,5 & 224 \\
\hline Luchtvaarttechnologie & 0,4 & 79,9 & 14,19 & 27,4 & 65,7 & 125 \\
\hline Maritiem officier & 0,7 & 46,9 & 14,70 & 7,1 & 70,3 & 136 \\
\hline Milieugerichte Materiaaltechnologie & $x$ & $x$ & $x$ & $x$ & $x$ & 13 \\
\hline
\end{tabular}




\begin{tabular}{|c|c|c|c|c|c|c|}
\hline HTO Bachelor-opleiding & Werkloosheid & $\begin{array}{r}\text { Werkzaam in } \\
\text { kerndomein } \\
\%\end{array}$ & $\begin{array}{r}\text { gem. } \\
\text { Bruto } \\
\text { uurloon } \\
€\end{array}$ & $\begin{array}{r}\begin{array}{r}\text { Spijt } \\
\text { opleiding }\end{array} \\
\%\end{array}$ & $\begin{array}{r}\text { Tevreden } \\
\text { met } \\
\text { functie } \\
\%\end{array}$ & Aantal \\
\hline Milieukunde & 6,2 & 77,8 & 13,87 & 27,0 & 61,0 & 176 \\
\hline Milieutechnologie & 2,5 & 85,9 & 13,22 & 25,5 & 77,6 & 77 \\
\hline Netwerk Infrastructuur Design & 2,1 & 79,4 & 13,92 & 13,3 & 77,7 & 79 \\
\hline Optometrie & 0,0 & 96,6 & 15,85 & 12,4 & 76,5 & 78 \\
\hline Ruimtelijke Ordening en Planologie & 5,0 & 81,3 & 14,12 & 27,9 & 71,2 & 270 \\
\hline Scheepsbouwkunde & 2,3 & 85,8 & 14,72 & 10,7 & 78,7 & 61 \\
\hline Technische Bedrijfskunde & 4,0 & 66,8 & 14,27 & 15,0 & 67,6 & 1063 \\
\hline Technische Commerciële Textielkunde & 2,1 & 71,0 & 11,63 & 23,1 & 70,5 & 54 \\
\hline Technische Informatica & 5,0 & 85,0 & 14,71 & 12,7 & 75,6 & 445 \\
\hline Technische Natuurkunde & 4,3 & 82,4 & 15,39 & 9,2 & 78,6 & 138 \\
\hline Verkeerskunde & 3,1 & 88,9 & 14,25 & 10,4 & 82,4 & 107 \\
\hline Werktuigbouwkunde & 2,4 & 83,9 & 14,96 & 12,4 & 72,0 & 1505 \\
\hline Wiskunde & 8,8 & 79,7 & 14,28 & 14,2 & 58,5 & 59 \\
\hline Totaal HTO Bachelor & 3,4 & 79 & 14,26 & 16,3 & 72,4 & 12955 \\
\hline Totaal HBO Bachelor & 4,8 & 70,5 & 13,69 & 19,8 & 67,7 & 70409 \\
\hline
\end{tabular}

$X=$ te weinig waarnemingen (in de periode $2006-2010$ in totaal minder dan 20 respondenten)

Opleidingen waarvoor in de periode 2006-2010 in een of meerdere jaren geen gegevens beschikbaar waren, zijn gearceerd.

Bron: HBO-Monitor 2006-2010

\section{Toelichting}

- Werkloosheid: Het werkloosheidspercentage heeft betrekking op de werkloze beroepsbevolking: schoolverlaters zonder werk (of met werk van minder dan 12 uur per week) die op zoek zijn naar betaald werk. Daarbij is tevens als voorwaarde gesteld dat de maatschappelijke positie niet scholier of student is.

- Kerndomein: Het percentage dat aangeeft dat het door de werkgever vereiste opleidingsniveau minimaal HBO is en dat de door de werkgever vereiste opleidingsrichting overeenkomt met of verwant is aan de eigen opleidingsrichting.

- Bruto uurloon: Dit betreft het gemiddelde bruto inkomen in de hoofdfunctie. Dit is inclusief toeslagen maar exclusief inkomen uit overwerk. Er is hier niet gecorrigeerd voor verschillen in leeftijd van de schoolverlaters, maar wel voor inflatie.

- Spijt opleiding: Het percentage dat aangeeft achteraf gezien voor een andere opleiding op hetzelfde of ander niveau te hebben willen kiezen.

- Tevredenheid: Hoe tevreden bent u met uw huidige functie (1'zeer ontevreden' tot en met 5 'zeer tevreden'. Vermeld is het percentage van antwoordcategorie 4 en 5 . 